\section{1}

\title{
Multi-stage kimberlite evolution tracked in zoned olivine from the Benfontein sill, South Africa
}

Geoffrey H. Howarth ${ }^{1}$, and Lawrence A. Taylor ${ }^{2}$

${ }^{1}$ Department of Geological Sciences, University of Cape Town, Rondebosch 7701, South Africa-

${ }^{2}$ Planetary Geosciences Institute, Earth and Planetary Sciences Dept., The University of Tennessee, Knoxville, TN, 37996 USA

Submitted to: Lithos

\section{Abstract}

Olivine is the dominant mineral present in kimberlite magmas; however, due to the volatile-rich nature of most kimberlites, they rarely survive late-stage serpentinisation. Here we present major and trace element data for a rare example of ultra-fresh olivine in a macrocrystic calcite kimberlite from the Benfontein kimberlite sill complex. Olivines are characterised by xenocrystic cores surrounded by multiple growth zones representing melt crystallisation and late-stage equilibration. Two distinct core populations are distinguished: Type 1) low Fo (88-89), Ni-rich, Ca- and Na-rich cores, interpreted here to be the result of carbonate-silicate metasomatism potentially as part of the earliest stages of kimberlite magmatism, and Type 2) high Fo (91-93), Ni-rich, low-Ca cores derived from a typical garnet peridotite mantle source. In both cases, the cores have transitional margins $\left(\mathrm{Fo}_{89-90}\right)$ representing equilibration with a proto-kimberlite melt. Trace element concentrations, in particular $\mathrm{Cr}$, of these transition zones suggest formation of the proto-kimberlite melt through assimilation of orthopyroxene from the surrounding garnet peridotite lithology. Trace element trends in the surrounding melt-zone olivine $\left(\mathrm{Fo}_{87}\right.$ 90) suggest evolution of the kimberlite through progressive olivine crystallisation. The final stages of olivine growth are represented by Fe-rich $\left(\mathrm{Fo}_{85}\right)$ and P-rich olivine indicating kimberlite evolution to mafic compositions. Fine $(<60 \mu \mathrm{m})$, Mg-rich olivine rims ( Fo94-98 $\left._{98}\right)$ represent equilibration with the final stages of kimberlite evolution back to Fe-poor carbonatitic melts. 


\section{Howarth and Taylor - Zoned olivine from the Benfontein kimberlite, South Africa}

We present a step-by-step model for kimberlite magma genesis and evolution from mantle to crust tracked by the chemistry of olivines in the Benfontein kimberlite. These steps include early stages of metasomatism and mantle assimilation followed by direct crystallisation of the kimberlite melt and late-stage equilibration with the evolved carbonatitic residual liquids. The Ca contents of the Type 1 xenocrystic olivines are the highest yet measured for mantle olivines, and do not overlap with any known mantle xenolith lithologies. These olivines likely represent an important stage of metasomatism directly related to the early stages of kimberlite melt ponding at the base of the lithospheric mantle.

\section{Introduction}

Kimberlites are complex, hybrid magmas that formed in the upper asthenosphere or lower lithosphere, migrating upward through the sub-continental lithospheric mantle (SCLM), assimilating and interacting with peridotitic diamond-bearing material (e.g., le Roex et al., 2003; Mitchell, 2008; Arndt et al., 2010; Russell et al., 2012; Bussweiler et al., 2016; Soltys et al., 2016). The resultant magmas are generally olivine-rich ( 50 vol. \%) when unaffected by later fractionation in the crust (e.g., Clement and Skinner, 1985). In the past, olivines have been divided into two populations based on morphology and size: 1) those with rounded morphology and $>0.5 \mathrm{~mm}$ in size were termed macrocrysts and were believed to represent xenocrystic material from the base of the SCLM; and 2) Olivine crystals with subhedral to euhedral morphologies and $<0.5 \mathrm{~mm}$ were termed phenocrysts and believed to represent primary olivine crystallising from the kimberlitic melt (e.g., Clement and Skinner, 1985). However, it has now been well documented that this sub-division is not correct, and that almost all olivines grains contain cores of xenocrystic material (e.g., Kamenetsky et al., 2008; Brett et al., 2009; Arndt et al., 2010; Pilbeam et al., 2013; Bussweiler et al. 2015; this study). The xenocrystic cores are generally mantled by olivine crystallising directly from the kimberlite through nucleation on pre-exiting olivines, regardless of size. These mantles represent the true 'primocrystic' kimberlite olivines. In addition, thin high-Mg rinds ( Fo $\left._{96-98}\right)$ are also observed in the most fresh kimberlite samples (e.g., Bussweiler et al., 2015). Therefore, individual olivine grains in kimberlite magmas record complex processes occurring from great depths ( 200-250 km) in the SCLM to upper-crustal levels during the final stages of kimberlite melt evolution. The major hindrance in the study of kimberlitic olivines is their tendency to be serpentinized. The best preserved examples are those from calcite kimberlites where, presumably, the water contents are lower than other kimberlites, allowing for the preservation of fresh olivine. Such calcite kimberlites are particularly abundant in Canada (e.g., Brett et al., 2009; Bussweiler et al., 2015), Greenland (e.g., 


\section{(86}

Arndt et al., 2010; Pilbeam et al., 2013). Calcite kimberlites are less common in the Kaapvaal craton (South Africa); however, there are several good examples available for study, such as the Benfontein sill complex and dikes associated with De Beers kimberlite. (e.g., Dawson and Hawthorne, 1973; Moore, 1988).

\section{Despite many recent studies on fresh olivines from numerous localities worldwide, several} contrasting hypotheses exist for the origin of both xenocrystic olivine cores and the kimberlitic mantles. Arndt et al. (2010) present a model based on abundant dunite nodules in Greenland kimberlites, where xenocrystic olivine cores are effectively the result of 'metasomatic defertilisation' of the lithospheric mantle wall rock during proto-kimberlite development. The defertilised material is then incorporated into the kimberlite, once it begins the ascent to the surface. Such a model is supported by the recent study of Cordier et al. (2015). In contrast, Bussweiler et al. (2015) suggested that the xenocrystic cores within Canadian kimberlites represent multiple mantle sources of harzburgitic and Iherzolitic compositions that were incorporated into the kimberlite en route to the surface. In the case of the kimberlitic melt-zone olivines, Pilbeam et al. (2013) proposed a process termed 'digestion fractional crystallisation', where orthopyroxene in the mantle is rapidly dissolved in the kimberlite melt facilitating new growth of kimberlitic olivine on pre-existing xenocrystic cores. This model is supported in the recent work of Bussweiler et al. (2015). However, Cordier et al. (2015) argued that with a higher $D_{\mathrm{Ni}}(>20)$, the olivine melt-zones can be explained through olivine crystallisation alone, without requiring orthopyroxene assimilation. In complete contrast with other models, Moore (2012) favours a model for a phenocrystic origin of the high-Mg olivines and little to no xenocrystic component, where the Fe-rich olivine cores are related to the megacrystic suite believed to have crystallised from early stage, protokimberlitic melts in the SCLM. There obviously exist several schemes for the origin and growth of kimberlitic olivine, each with its subtle, albeit complex variants that are probably a function of different kimberlite evolutions. Therefore, many questions on the origin of olivine in kimberlites remain unresolved and require further detailed work on the kimberlites from different localities worldwide.

87

In order to continue the ongoing debate on the origin of olivine in kimberlite, we present a detailed petrographic and geochemical study on olivines from a particularly fresh calcite kimberlite from the Benfontein sill complex, South Africa. Major and minor element compositions were obtained using high beam current (60 nA). electron microprobe analyses, whereas trace elements were analysed with the 
91 Laser Ablation ICP-MS technique. Our results support a hybrid origin for olivines in kimberlites and

92 provide new insights into the evolution of kimberlitic magmas from initiation in the deep mantle to 93 upper-crustal levels during late-stage evolution to carbonatitic compositions. These interpretation are

94 applicable to kimberlites worldwide and provide further constraints for the building database for the 95 origin of olivine in kimberlites.

\section{Benfontein kimberlite sill complex}

The Benfontein sill complex is located $\sim 8 \mathrm{~km}$ south-east of Kimberley, in association with an important zone of kimberlite pipes and sills striking NE-SW (Figure 1). The sill complex is composed of three separate laterally extensive units, simply termed the lower, middle, and upper sills (Dawson and Hawthorne, 1973). The complex is hosted within shales of the lower most Karoo Supergroup unit, the Dwyka Group, and outcrops over an area of $4.5 \mathrm{~km}$ east-west and $2.5 \mathrm{~km}$ north-south. The region has also been intruded by a large Karoo dolerite sill, which has been tracked over an area of $13,000 \mathrm{~km}^{2}$ and referred to as the Kimberley sheet. The dolerite sheet forms the 'cap-rock' to the sill in most, but not all, locations (Dawson and Hawthorne, 1973). Palaeo-stratigraphic recreation of the Kimberley region, based on the upper-crustal xenoliths located within the kimberlite pipes, suggests that at least $1000 \mathrm{~m}$ of post-emplacement erosion has occurred in the region (Hanson et al., 2009), indicating an emplacement depth of the sills at $1000 \mathrm{~m}$ from the original land surface.

The kimberlite sills are composed of numerous layers that resulted from multiple injections of magma. Cumulate textures are common, and differentiation of the magma has been interpreted to be

112 occurring both at depth and within the sills (Dawson and Hawthorne, 1973). Dawson and Hawthorne 113 (1973) described units consisting of a sequence, from bottom up: 1) an olivine cumulate layer; 2) olivine114 spinel cumulate layer; and 3) spinel-perovskite cumulate layer. In addition, layers of carbonate and carbonate-apatite are also present within the sills (e.g., Dawson and Hawthorne, 1973). Other layers with less well-defined cumulus textures are composed of typical kimberlitic minerals, including:

117 megacrysts (olivine, garnet, phlogopite, etc.) and primary minerals of olivine, spinel, perovskite, apatite, calcite, dolomite, ankerite, and quartz (Dawson and Hawthorne, 1973). Calcite is the dominant interstitial phase, and is observed in several textural settings. In particular, late-stage spherical segregations are observed, consisting dominantly of calcite with lesser mica, spinel, and quartz. 
121 Serpentine is a rare, yet present phase associated with these textures. Calcite-rich diapirs are observed 122 migrating upward from carbonate-rich layers, through denser olivine cumulate and spinel-perovskite

123 cumulate layers. These textures are strong evidence for the differentiation of kimberlitic magmas to 124 late-stage carbonatitic liquids through fractionation of primary phases (Dawson and Hawthorne, 1973).

125

126

127

128

129

130

131

132

133

134

135

136

137

138

139

140

141

142

143

144

145

146

147

148

\section{Sample and analytical techniques}

The kimberlite from the Benfontein sill analyzed in this study, sample number JJG 2241, was obtained from the 'Mantle Collection', initiated by Prof. John Gurney, and housed at the University of Cape Town. The sample is available on request for further study from the first author GHH. The sample is one of a larger collection of samples from the Benfontein sill complex, spanning a full range from the lower, middle, and upper sills. Detailed petrographic description of the sample is given in section 4.

\subsection{Electron Microprobe}

Olivine in the Benfontein macrocrystic kimberlite was analyzed for major and minor elements using a JEOL Superprobe JXA-8100 Electron Probe Microanalyzer at the University of Cape Town. The analyses were performed with wavelength dispersive spectrometers (WDS), using an accelerating potential of 15 $\mathrm{kV}$, a beam current of $60 \mathrm{nA}$, and a $3 \mu \mathrm{m}$ diameter beam. Counting time were $10 \mathrm{~s}$ for Si, Fe, Mg, Ti; $40 \mathrm{~s}$ for $\mathrm{Ca}$ and $\mathrm{P}$; and $60 \mathrm{~s}$ for $\mathrm{Ni}$ and $\mathrm{Mn}$. The theoretical detection limits for such an analytical protocol are 60 ppm for $\mathrm{Ni}$, 30 ppm for $\mathrm{Ca}$, and 80 ppm for $\mathrm{Mn}$, although as suggested by Pilbeam et al. (2013), a more realistic detection limit of 100 ppm (0.01 wt.\%) should be used for all trace elements. The oxide phases were analyzed in separate sessions using a different setup, with an accelerating potential of 15 $\mathrm{kV}$, a beam current of $20 \mathrm{nA}$, and counting times of $10 \mathrm{~s}$ on peak for all elements. Elemental X-ray maps for individual olivine grains were collected using the CAMECA SX-100 Electron Microprobe at the University of Tennessee. The following conditions were used for collection; $15 \mathrm{kV}$ accelerating voltage, $100 \mathrm{nA}$ beam current, $800 \mathrm{~ms}$ count time, and a $2 \mu \mathrm{m}$ stage step.

\subsection{Laser Ablation ICP-MS}


Trace elements concentrations for the Benfontein olivines were analysed using the New Wave UP213 solid-state laser ablation system, attached to a Thermo-Fisher X-series II quadrupole ICP-MS at the University of Cape Town. Beam size was set at $55 \mu \mathrm{m}$, so as to be able to resolve individual zones.

152 Each spot analysis was measured for $50 \mathrm{~s}$ with $30 \mathrm{~s}$ background measurement. The laser was routinely 153 run with a repetition rate of $10 \mathrm{~Hz}$ and energies of 0.5-1 mJ per pulse. Argon was used as a carrier gas for transport of material to the ICP-MS. Reference material NIST 610 and NIST 612 were used as calibration standards and were run every 10-12 spots. In addition, NIST 612 was routinely run as an unknown to check precision of the instrument. For trace elements, reproducibility, of the reference material, NIST 612 was better than $6 \%$. Data with greater than $10 \%$ error were discarded. The isotope PlasmaLab associated with the instrument, Si from microprobe analyses, and making use of 2-3 separate windows of interest over the collected signals for each spot. The data for each of the three windows was then further processed in excel to check reproducibility. Furthermore, no significant variation was observed down-hole during data reduction of individual spots.

\section{Results}

The kimberlite sample JJG 2241 is from the Middle sill and consists of abundant fresh olivines, ranging in size from $\mathrm{mm}$-scale (macrocrysts) down to $100 \mu \mathrm{m}$ (often termed phenocrysts). As will be shown throughout this contribution, the terminology is misleading, as almost all olivines regardless of the size and morphology contain xenocrystic cores. The olivines vary in morphology from rounded grains, to angular, and subhedral-euhedral shapes. No distinct correlation of morphology with grain size

170 is observed, although in general, the fine-grained olivines are subhedral, whereas coarser grained 171 varieties are generally more rounded in morphology. The olivines are very fresh relative to in typical 172 kimberlites, although they are characterised by thin serpentine margins, indicating some degree of 173 alteration by late-stage, water-rich fluids. The olivines can be broadly divided into two subgroups based 174 on the zonation noted in BSE images, and the corresponding compositions. These subgroups have no 175 correlation with grain size or morphology. They are simply termed Type 1 and Type 2 olivines, and are 176 described in detail below. Olivines occur as both single grains as well as polycrystalline aggregates

177 (Figure 2). The interstitial kimberlite material is composed of spinel, ilmenite, perovskite, and 178 monticellite set in a base of calcite. Calcite forms poikilitic blades up to $2 \mathrm{~mm}$ in length enclosing early 179 crystallised phases. In addition, large plates of non-poikilitic calcite are also present, as observed in 
180

181

201

other studies (e.g., Dawson and Hawthorne, 1973). Spinel grains are euhedral and often contain rims of perovskite, indicating spinel crystallisation prior to the increase in Ca activity that created the perovskite. Monticellite is very fine-grained imparting a 'sugary' texture to the rock, typical of Group I kimberlites. The rock can be classified as a Group I, hypabyssal-facies, uniform, macrocrystic (noncumulate), calcite kimberlite.

\subsection{Type 1 and Type 2 olivine core chemistry}

The Type 1 olivines are characterised by zoned cores from generally lower Fo contents of 8889(Table 1; Figure 3). In contrast, the Type 2 olivine cores are Mg-rich with higher Fo contents of 92-93 (Figure 2, 3 and 5).

$$
\text { Both the Type } 1 \text { and Type } 2 \text { olivines are characterized by high Ni contents, generally >2500 ppm, }
$$
with two Type 1 cores as exceptions at 2017 ppm and 2241 ppm, respectively (Figure 6; Table 2). The Type 1 and Type 2 cores are distinct from each other in most other trace elements analysed; the Type 1 generally have higher trace element concentrations relative to the Type 2, including: Ca (550-800 ppm, relative to $140-560 \mathrm{ppm}), \mathrm{Co}(140-165 \mathrm{ppm}$, relative to $110-140 \mathrm{ppm}), \mathrm{Mn}$ (770-900 ppm, relative to 650-775 ppm), Al (240-650 ppm, relative to 38-290 ppm), V (7-12 ppm, relative to 3.0-5.8 ppm), Zn (70$100 \mathrm{ppm}$, relative to $47-67 \mathrm{ppm}), \mathrm{Cu}(4.0-6.5 \mathrm{ppm}$, relative to $0.6-5.0 \mathrm{ppm})$, and $\mathrm{Na}$ (180-560 ppm, relative to $45-210$ ppm) (Figure 6). In addition, Type 1 cores generally have higher Li concentrations (1.7$4.4 \mathrm{ppm}$ ) relative to the Type 2 cores (1.2-2.3 ppm). Furthermore, the Type 1 and Type 2 cores have distinct $\mathrm{V} / \mathrm{Sc}$ values of 3.7-4.2 and 1.3-2.9, respectively.

\subsection{Transition-zone olivine chemistry}

Both the Type 1 and Type 2 cores are surrounded by a gradational transition-zone separating the core from the more Fe-rich melt-zone (Figure 2, 3, 4, and 5). These transitional regions range in composition from the upper limit observed from the Type 1 cores $\left(\mathrm{Fo}_{89}\right)$ to the lower range of the Type 2 cores $\left(\sim \mathrm{Fo}_{91}\right)$. In BSE images, the transition zones are clear and gradational in texture. The trace element chemistry is generally transitional between the Type 1 and Type 2 cores, similar to that of the Fo contents; however, the Ni contents are, on average, higher than the cores (Figure 5). Trace element 
maps show that the $\mathrm{Cr}$ contents are also slightly higher in the transition-zone olivine (>400 ppm), relative to the cores and melt-zones, with a couple of exceptions, where Type 1 cores overlap in $\mathrm{Cr}$ contents with the transition-zone (Figure 7e).

\subsection{Olivine melt-zone chemistry}

Both Type 1 and Type 2 olivines contain distinctly low Fo (87-89) mantles surrounding the core regions. These mantles are of similar compositions and are described together. The mantle regions are termed 'melt-zone' here; for reasons discussed below, they are believed to represent the crystallisation product from a kimberlite melt. The melt-zones are characterised by relatively constant Fo content; however, Ni shows a gradational decrease throughout the zone (Figure $\mathbf{3}$ and 5). Interestingly, two distinct melt-zone trends are observed in Figure 3. These two trends do not correlate with their spatial association with either Type 1 or 2 cores. This feature has not previously been identified in kimberlitic olivines.

\section{Additional melt-zones are observed in rare grains. In the case of olivine \#3 (Figure 4b), two} additional melt-zones are observed and characterised by the lowest Fo contents analyzed in the Benfontein kimberlite in this study. The low Fo zone ranges in composition from $\mathrm{Fo}_{88}$ to $\mathrm{Fo}_{85}$ and is followed by another zone, where the Fo contents gradually increase back to compositions observed in melt-zone $1\left(\mathrm{Fo}_{88}\right)$ (Figure 4). This melt-zone 2 is characterised by a distinct increase in $\mathrm{P}_{2} \mathrm{O}_{5}$ as observed in X-ray maps (Figure 7).

$$
\text { In addition, cracks that cross-cut olivine cores are observed, with adjacent olivine compositions }
$$
similar to the melt-zone olivine. This is shown in Figure 5a, where the core regions have been partially modified to melt-zone compositions, with Fo contents of 88-89, surrounding cross-cutting cracks.

44 The melt-zone olivines generally overlap in trace element concentrations with that of the Type 1 and 2 cores; however, there are some trends observed in the trace elements relative to Ni contents. Notably, positive correlations are observed between $\mathrm{Ni}$ and $\mathrm{Co}$ and $\mathrm{V}$, whereas negative correlations are 


\section{Howarth and Taylor - Zoned olivine from the Benfontein kimberlite, South Africa}

237

238

239

240

241

242

243

244

245

246

247

248

249

250

251

252

253

254

255

256

257

258

observed between $\mathrm{Ni}$ and $\mathrm{Ca}, \mathrm{Mn}, \mathrm{Al}, \mathrm{Ti}$, and $\mathrm{Sc}$ (Figure 6). In addition, the melt-zone shows concurrent decrease in Ni with $\mathrm{V} / \mathrm{Sc}$ values.

\subsection{Olivine rim chemistry}

The outer rim compositions are similar for both Type 1 and Type 2 olivines. Depending on the extent of serpentinization of the olivine grains, up to three distinct rims are observed on any one olivine, although generally only one rim-zone is observed. The transition from melt-zone to rim composition is sharp and clearly observed in BSE images, and most notably in Mg X-ray maps (Figure 7). The rims are defined by increased Fo contents, with successive rim-zones increasing in Fo contents from $\mathrm{Fo}_{89}$ to $\mathrm{Fo}_{94}$ and up to extremely $\mathrm{Mg}$-rich $\mathrm{Fo}_{97}$ outermost rims (Figure 3). The rims are characterised by very low $\mathrm{Ni}$ (100-650 ppm) and significant increases in Ca (3000-7600 ppm) and Mn (1000-2000 ppm) (Figure 6). Similarly to the Fo contents, the Ca and Mn contents increase outward with sharp increase associated with the high $\mathrm{Fo}_{97}$ outer rims (Figure 4). In general, the rims are characterised by an increases in Sc and $\mathrm{Ti}$ and decreases in $\mathrm{Co}, \mathrm{Zn}$, and $\mathrm{Cr}$, relative to the melt-zone. In addition, the rim has lower $\mathrm{V} / \mathrm{Sc}$ value than both the melt-zone and the Type 1 and 2 cores.

\subsection{Oxide minerals}

Oxide minerals, ilmenite and spinels of various compositions, are observed as inclusions within both olivines types, but never within the cores. Chromite grains are also observed in the melt-zone, and sometimes in contact with the core regions. In addition, oxide minerals are observed in the outer rims, either partly or wholly enclosed in the olivine. They are also an abundant constituent of the groundmass kimberlite interstitial to the olivines. These phases were analyzed in all three textural associations and distinct differences were observed.

$$
\text { The oxide minerals observed within the melt-zone of the olivines are chromites (45-50 wt.\% } \mathrm{Cr}_{2} \mathrm{O}_{3} \text { ) }
$$
with compositions of $\sim \mathrm{Chr}_{62} \mathrm{Sp}_{14} \mathrm{Ulv}_{12} \mathrm{Mt}_{12}$. The oxide minerals associated with the margins of the olivines vary in compositions from Mg-rich (13-14 wt.\%) ilmenites to $\mathrm{Cr}$-poor (<3 wt.\%) titanomagnetite, with compositions of $\mathrm{Chr}_{1} \mathrm{Sp}_{12} \mathrm{Ulv}_{52} \mathrm{Mt}_{35}$. The groundmass oxide minerals outside of the olivine grains are of 
similar compositions to the $\mathrm{Cr}$-poor, Fe- and Ti-rich spinels, with an average composition of $\mathrm{Chr}_{0.1} \mathrm{Sp}_{12} \mathrm{Ulv}_{52} \mathrm{Mt}_{36}$, included within the outer regions of the olivines.

\section{Discussion}

\subsection{Depleted and metasomatised sources for olivine cores}

The high $\mathrm{Ni}(>2500 \mathrm{ppm})$ and generally low Ca $(<800 \mathrm{ppm})$ contents, in addition to the resorbed and/or angular morphology, of both the Type 1 and Type 2 cores, are consistent with derivation from the SCLM as xenocrysts within the Benfontein kimberlite parental magma. This interpretation is consistent with many recent studies of kimberlites worldwide (e.g., Kamenetsky et al., 2008; Brett et al., 2009; Arndt et al., 2010; Pilbeam et al., 2013; Bussweiler et al., 2015). Bussweiler et al. (2015) showed that the chemistry of olivine cores from Canadian kimberlites imply two different mantle lithologies, derived from a layered SCLM, with a deeper, more fertile Iherzolitic component and a shallower, more depleted harzburgitic component. Arndt et al. (2010) proposed a model for olivine formation surrounding the initial kimberlite melt at the base of the lithosphere through a process they termed 'metasomatic defertilisation'. They suggested that an intruding $\mathrm{C}-\mathrm{H}-\mathrm{O}$ fluid/melt assimilated orthopyroxene and garnet ( \pm clinopyroxene), and all that remained was an aureole of metasomatised dunite, which is then entrained, once the kimberlite magma begins ascent to the surface. In the following section, we discuss the origin of the Type 1 and 2 cores at the Benfontein kimberlite, in context with these recent studies. This will be achieved using chemical tracers, allowing for constraints to be placed on the composition of the rock from which olivine was sourced, the equilibration temperature, and the composition of metasomatic fluids/melts circulating at the base of the SCLM.

\subsubsection{Source rock lithology}

De Hoog et al. (2010) showed that olivines in garnet- versus spinel-bearing mantle lithologies can be distinguished based on the Al-Mn and Sc-Zr variations. The Type 1 and Type 2 cores both plot within the field defined for garnet peridotite (Figure 8a), implying an origin at depth within the garnet stability field (i.e., > $20 \mathrm{kbar}$ ). This is consistent with the common occurrence of garnet peridotite xenoliths within kimberlites of the Kimberley region. The Fo contents for olivines analysed from harzburgite and Iherzolite mantle xenoliths from the Kimberley region range from $\mathrm{Fo}_{89}$ to $\mathrm{Fo}_{94}$ (e.g., Griffin et al., 1999; Rehfeldt et al., 2007; De Hoog et al., 2010). The Fo contents of the Type 2 olivine cores overlap those of 
orthopyroxene-rich harzburgitic and Iherzolitic xenoliths (Figure 3). In contrast, the Type 1 cores are significantly more Fe-rich than reported peridotite values. Other olivine-bearing materials with low Fo contents and obtained from the SCLM, via transport to the surface by kimberlites, are dunite xenoliths

$298\left(\mathrm{Fo}_{85}\right.$ to $\left.\mathrm{Fo}_{91}\right)$ and olivine megacrysts $\left(\mathrm{Fo}_{78}\right.$ to $\left.\mathrm{Fo}_{88}\right)$ (Figure 3). The Fo contents of Type 1 cores overlap with those of the dunite xenoliths, but not the megacryst suite olivines (Figure 3). The high Fe contents of these dunites and the Type 1 Benfontein cores preclude a restitic origin (e.g., Rehfeldt et al., 2007). The Fe-rich dunites reported by Rehfeldt et al. (2007) were interpreted to reflect recrystallized cumulates related to the Karoo flood basalt volcanism. Other rare mantle xenoliths from the Kimberley region with olivine Fo contents ranging from 89 to 93 are dunites, wehrlites, and websterites, which are interpreted to represent residues that have been enriched through melt metasomatism (Rehfeldt et al., 2008). The enrichment results in increases in $\mathrm{CaO}, \mathrm{Al}_{2} \mathrm{O}_{3}, \mathrm{FeO}$, and the high field strength elements (HFSE) (Rehfeldt et al., 2008), similar to the increases in geochemical components observed for the Type

3071 cores. Similar low Fo contents are also reported in rare cases for sheared peridotites interpreted to form at the base of the SCLM (Hervig et al., 1986). Alternatively, the Type 1 cores also overlap in composition with the so called 'defertilised' dunite compositions, suggested by Arndt et al. (2010), which are also consistent with the highly variable, yet generally, relatively fine-grain size of the olivine. In addition, olivines analysed within carbonatitic melt inclusions from mantle xenoliths have Fo contents of 88 (Giuliani et al., 2014), implying a carbonatitic affinity is also possible for the Type 1 cores. The effects of metasomatism on the Type 1 and 2 cores will be assessed in the following section, with specific interest to the origin of the Type 1 cores. trace element concentrations. Seitz and Woodland (2000) showed that Li concentrations of olivines in granular geochemically depleted mantle xenoliths are in the range of 1-2 ppm, whereas metasomatised xenoliths have olivines with up to $5 \mathrm{ppm} \mathrm{Li}$. The Li concentrations of the Type 1 and 2 cores form a

321 continuum, with concentrations of 1.7-4.5 ppm and 1.3-2.3 ppm (Table 2), respectively. This would 322 suggest a metasomatic control on the origin of the Li concentrations in the Type 1 cores. Copper is 323 similarly enriched in more metasomatised rocks; for example, metasomatised Kaapvaal peridotites 324 contain up to $70 \mathrm{ppm} \mathrm{Cu}$, relative to typical mantle rocks of $<5 \mathrm{ppm}$ (De Hoog et al., 2010). This again 325 suggests that the elevated Cu observed for the Type 1 olivines indicates a metasomatic control. The 
326 Type 1 olivines also have elevated concentrations of $\mathrm{Ca}, \mathrm{Na}, \mathrm{Al}, \mathrm{Mn}, \mathrm{Co}$, and $\mathrm{Zn}$. Generally, mantle olivine 327 contains $<600$ ppm Ca (e.g., Foley et al., 2013), whereas the Type 1 cores were measured with Ca in the 328 range of 550-800 ppm. The Fe-rich dunites, websterites, and wehrlites reported by Rehfeldt et al. (2007; 329 2008) have Ca contents ranging from 70-400, with one dunite sample with neoblastic olivine with 550 ppm Ca (Rehfeldt et al., 2007; 2008). In rare cases, sheared garnet peridotite xenoliths from kimberlites are observed with Ca concentrations of 600-700 ppm (Hervig et al., 1986). In addition, sheared peridotites from lithospheric localities worldwide may have high Fe contents (as low as Fo 86; Agashev et al., 2013), and overlapping the Fo contents of the Type 1 olivines. Sheared peridotites are generally interpreted to form at the base of the SCLM at high temperatures through metasomatic re-fertilisation of granular garnet peridotite (e.g., Agashev et al., 2013; Howarth et al., 2014), and represent a potential source for the Type 1 olivines. The only other localities where mantle olivines have been observed with $>600$ ppm Ca are from rocks associated with intraplate ocean island volcanism, such as the Canary Islands (e.g., Neumann et al., 2002), or associated with rift-related settings from Antarctica and East Africa (e.g., Foley et al., 2006; Kaeser et al., 2006). Indeed, other trace elements enriched in the Type 1 olivine cores, versus the Type 2 olivine cores, are also enriched in the Canary Island mantle olivines, 341 including overlapping concentrations of $\mathrm{Li}, \mathrm{Zn}, \mathrm{Co}$, and Ti. Furthermore, the Fo contents of the Type 1 342 olivine cores also overlap with those of the Canary Island olivines, which extend to values of $\mathrm{Fo}_{89}$ 343 (Neumann et al., 2002). Neumann et al. (2002) and Foley et al. (2013) suggested that the positive correlation in $\mathrm{Ca}$ and $\mathrm{Ti}$ in olivine from mantle xenoliths from the Canary Islands and other rift-related settings indicates a metasomatic control by a high pressure carbonate-silicate melt (Figure $\mathbf{8 b}$ ). In addition, the enrichment of $\mathrm{Na}$ in the T1 Benfontein cores implies that the metasomatism had an alkalirich character. Therefore, the Type 1 olivine cores overlap with some sheared peridotites, as well as metasomatised olivines entrained in intraplate/rift-related volcanism, indicating a metasomatic origin. The question remains: are the Type 1 olivine cores simply xenocrysts of metasomatised mantle material, or do they represent an early stage of kimberlite development? Giuliani et al. (2016) showed that

351 phlogopite macrocrysts have rim compositions similar to typical kimberlitic phlogopite, and interpreted 352 these to represent 'antecrysts', formed by earlier kimberlite pulses making use of the same conduit. In 353 addition, numerous recent studies have shown that the early kimberlite melt is highly reactive and 354 interacts/assimilates with silicate minerals; not only orthopyroxene, but clinopyroxene and garnet as 355 well (e.g., Bussweiler et al., 2016; Soltys et al., 2016). 


\section{Howarth and Taylor - Zoned olivine from the Benfontein kimberlite, South Africa}

The rarity of mantle xenoliths with olivine compositions overlapping the Type 1 cores, the generally resorbed morphology, the polycrystalline texture of the grains and the high abundance of Type 1 cores all suggest to us that the metasomatic control is directly related to early stages of kimberlite melt formation in the mantle, and may also represent olivine in equilibrium with the kimberlite melt; i.e., 'antecrysts'. In this regard, we favour a model for early stage kimberlite melt development at the base of the SCLM through interaction and equilibration with surrounding mantle lithologies, similar to the model of metasomatic defertilisation presented by Arndt et al. (2010). The recent studies of Bussweiler et al. (2016) and Soltys et al. (2016) have shown that early kimberlite melts will indeed assimilate silicate minerals further supporting the notion of the development of an olivine-rich metasomatic aureole surrounding the early kimberlite melt at the base of the mantle.

\subsubsection{Relative equilibration temperatures}

De Hoog et al. (2010) recently calibrated a thermometer for mantle olivine using olivine Al concentrations and the olivine $\mathrm{Cr} \#(\mathrm{Cr} / \mathrm{Cr}+\mathrm{Al})$, as well as the pressure of formation/equilibration in the SCLM. While the Al concentrations and the $\mathrm{Cr} \#$ are easily obtained for single olivine grains, the pressure is not. Therefore, we have used estimates of pressure based on the general location of garnet peridotites within the mantle (i.e., 40-70 kbar). Temperatures were then calculated using the thermometer of De Hoog et al. (2010) at pressure of 40, 50, 60, and 70 kbar and compared with other data for Kaapvaal xenoliths (Figure 9). The average calculated temperatures for Type 1 cores, at 40, 50, 60 , and 70 kbar pressure, are $1383,1451,1520$, and $1588^{\circ} \mathrm{C}$, respectively. In contrast, the average calculated temperatures for the Type 2 cores are $1158,1218,1277,1337^{\circ} \mathrm{C}$, respectively. A full range of data is plotted in Figure 9. Relative to the calculated geotherm for the Kaapvaal craton and data for xenoliths reported in the literature (e.g., Woodland and Koch, 2003; Lazarov et al., 2009), the Type 2 cores are likely equilibrated at depths of 40-60 kbar and the temperatures are consistent with typical peridotite xenoliths (Figure 9). In contrast, the temperatures calculated for the Type 1 cores do not intersect the geotherm or the field for other mantle xenoliths (Figure 9). The temperature of kimberlitic melts at the base of the SCLM has been inferred at $1350-1450^{\circ} \mathrm{C}$ (e.g., Priestley et al. 2006; Sparks, 2013). These temperatures overlap with those calculated for the Type 1 cores. This suggests that the Type 1 cores are likely indicative of high-T metasomatism at the base of the SCLM, consistent with interpretations of a metasomatic origin for high Fe and trace element contents. 
Howarth and Taylor - Zoned olivine from the Benfontein kimberlite, South Africa

\subsubsection{Summary: Origin of Type 1 and Type 2 cores}

The high Fo content and generally low trace element concentrations of the Type 2 cores are consistent with derivation from orthopyroxene-rich peridotitic lithologies. These are the most common lithologies observed as mantle xenoliths in the Kimberley region. In contrast, the low Fo contents and high $\mathrm{Ca}$ and $\mathrm{Na}$ concentrations of the Type 1 cores are not consistent with typical mantle xenoliths lithologies reported in the literature; including, the Fe-rich dunite, wehrlite, and websterite xenoliths. The only exception, to our knowledge, being the study of sheared peridotites of Hervig et al. (1986). However, the Type 1 cores do reflect melt metasomatism. The composition of the melt is difficult to constrain; however, based on the high $\mathrm{Ca}$ and $\mathrm{Na}$ of the Type 1 olivines, we suggest that this melt has a carbonate-silicate character, and high Na contents may also indicate an alkali-rich nature. Many recent studies suggest that kimberlite melts have a carbonatitic character to begin (e.g., Mitchell, 1970; McGetchin et al., 1973; Kamenetsky et al., 2004; Kamenetsky et al., 2008; Giuliani et al., 2012; Russell et al., 2012; Sparks, 2013; Brett et al., 2015; Soltys et al., 2016; Bussweiler et al., 2016). The Type 1 olivine Fo content allows us to constrain the Mg\# of the metasomatic melt. Using the Mg-Fe exchange coefficient of 0.5 and 0.6 (as suggested for $\mathrm{CO}_{2}$-rich melts), we estimate the $\mathrm{Mg \#}$ of the metasomatic melt as 78-81. Typical aphanitic kimberlites (i.e., the kimberlite composition at the surface) are estimated to have an Mg\# in the range of 82-88 (e.g., le Roex et al., 2003). Klein-BenDavid et al. (2004) reported carbonatitic fluid inclusions in diamonds with a large range in $\mathrm{Mg \#}$ from 59 to 82. Therefore, the Mg\# of 78-81 suggested here is lower than typically reported for kimberlite melt, but well within the spectrum of known carbonatitic compositions, within the diamond stability field.

In summary and based on the olivine chemistry discussed above, we suggest that the Type 1 olivine cores represent an early stage metasomatic event that occurred at depths equivalent to the base of the SCLM, at high temperatures $\left(\sim 1400^{\circ} \mathrm{C}\right)$, with an alkali-rich, carbonate-silicate melt composition, potentially carbonatitic in character, and with a $\mathrm{Mg \#} \mathrm{of} \mathrm{78-81.} \mathrm{This} \mathrm{metasomatic} \mathrm{event} \mathrm{may} \mathrm{or} \mathrm{may} \mathrm{not}$ be directly linked to the host kimberlite. Arndt et al. (2010) proposed a process of metasomatic defertilisation, which is an early stage of kimberlite related metasomatism and assimilation occurring as a halo around the kimberlite melt at the base of the SCLM. We suggest that the Type 1 cores represent a similar process of early stages of metasomatism by kimberlitic precursor and the development of the initial kimberlite conduit at the base of the SCLM, prior to rapid emplacement upward to the surface. 
In order to assess the evolution of kimberlite melts within the SCLM and en route to the surface, we discuss here the trace element variations in the melt- and transition-zone olivines, in context with

422 current models presented in the literature.

423

\subsubsection{Melt-zone kimberlitic olivine: Progressive olivine crystallisation}

The Fo contents observed for Benfontein melt-zone olivine are similar to other kimberlites of the Kaapvaal craton; for example, the De Beers kimberlite at $\sim \mathrm{Fo}_{88}$ (Moore, 1988) (Figure 3). Arndt et al. (2010) reported similar melt-zone olivine of $\mathrm{Fo}_{88}$ from a kimberlite (sample NCR27) of the Kangamiut region, Greenland. Kamenetsky et al. (2008) also reported similar melt-zones for olivines at $\mathrm{Fo}_{89}$ for the Udachnaya kimberlite, Siberia. Therefore, this melt-zone composition has been repeated in time and space and represents a relatively common kimberlite evolutionary path in different cratonic regions. An exception occurs with the Lac de Gras kimberlites, which appear to have formed from a more Mg-rich melt (e.g., Bussweiler et al., 2015). Similar Mg-rich melt-zone olivine have been reported for Group II kimberlites/orangeites from the Kaapvaal craton (e.g., Arndt et al., 2010; Moore, 2012).

In general, these previous studies interpret the melt-zone olivine as a product of crystallisation from the kimberlite magma, rather than an equilibration zone. The textural evidence observed in this study is ambiguous, indicating both primary crystallisation products and equilibration zones. The presence of chromite inclusions in the melt-zone clearly indicates concurrent crystallisation of both olivine and chromite from a kimberlite melt. In contrast, the relationships of the melt-zone on olivines grains around the margin, observed on dunite nodules (Figure 2e), indicate an equilibration zone, rather than a crystallisation product. Therefore, the melt-zone olivine represents both crystallisation of olivine onto pre-existing olivine cores and equilibration of olivine/dunite nodules with the kimberlite melt. In addition, the presence of cracks cross-cutting the higher Fo cores, which have equilibration zones with compositions similar to the melt-zones, indicates that the kimberlite melt at this stage was able to intrude along these fine cracks. Similar cracks and healed fractures were reported for olivines from Canadian kimberlites (e.g., Brett et al., 2009; Brett et al., 2015) and interpreted to represent decompression cracking. Therefore, these cracks with intruding kimberlite and equilibration of the cores to melt-zone compositions indicate formation of the melt-zone olivine during decompression. This 
decompression is likely related to transport to the surface; therefore, the melt-zone olivine crystallises en route to the surface and not at the base of the SCLM. buffering of the Mg-Fe during evolution. This is generally not consistent with a simple fractionation process as one would expect the Fo content to decrease to more Fe-rich compositions. This led Pilbeam et al. (2013) to suggest a process they termed 'digestion fractional crystallisation' where olivine crystallisation is accompanied by assimilation of entrained mantle orthopyroxene en route to the surface, which essentially buffers the Mg-Fe of the melt. However, Cordier et al. (2015) showed that this trend can similarly be explained by olivine crystallisation with a slightly higher olivine-melt partition coefficient $\left(D_{\mathrm{Ni}}>20\right)$.

In contrast to the Fo content of the melt-zone, plots of Ni versus other trace elements clearly show both positive and negative trends. Bussweiler et al. (2015) suggested that by comparing the ratios of partition coefficients for trace elements in the melt-zone, the effect of orthopyroxene assimilation could be assessed. They showed that trace elements enriched in the melt-zone have olivine-orthopyroxene partition coefficients $<1$, which was used as evidence for the assimilation of orthopyroxene. However, these elements are incompatible in olivine, and one would similarly expect these elements to increase in the melt through simple fractional crystallisation of olivine. Indeed, the opposite is true for compatible elements in olivine. In Figure 6, elements that are generally compatible in olivine, in typical basaltic systems (partition coefficients for olivine-kimberlite are not available), such as Co ( $K_{D}=3.0$; Foley et al., 2013) and $\mathrm{Zn}\left(\mathrm{K}_{\mathrm{D}}=1.1\right.$; Foley et al., 2013) show trends of decreasing Ni and Co-Zn, consistent with crystallisation of olivine. Similarly, incompatible elements show trends of decreasing $\mathrm{Ni}$, but increasing element X; e.g., Ca, Mn, and Ti (Figure 6), again consistent with fractional crystallisation of olivine. We interpret these trends to indicate olivine crystallisation and evolution of the melt en route to the surface, where the buffered Mg-Fe can be explained by a slightly higher partition coefficient than normal, as shown by Cordier et al. (2015). This interpretation does not preclude the assimilation of orthopyroxene (discussed below), but rather suggests that it is not necessary to explain the chemical trends of the melt-zone olivines. 
Howarth and Taylor - Zoned olivine from the Benfontein kimberlite, South Africa

\subsubsection{Transition zone olivine: Assimilation of orthopyroxene}

The cores of both Type 1 and Type 2 olivines are characterised by distinct rims that show gradational contacts and overlaps in compositions with each other, termed transition zones in the results section

(Figure 6). These transition zones have a composition of $\mathrm{Fo}_{89-91}$, similar to slightly higher $\mathrm{Ni}$ in their cores, as well as increased $\mathrm{Cr}$ contents. In addition, the Al contents decrease for the Type 1 transitions and increase for the Type 2 transitions, resulting in overlapping Al contents (Figure 6). The overlapping compositions of the transition zones and the gradational contact with their cores suggest that, in both Type 1 and 2 cores, they have partially equilibrated with the earliest stage of kimberlitic melt; i.e., the proto-kimberlite melt. The most distinct difference is the generally higher $\mathrm{Cr}$ contents (>400 ppm) relative to the cores $(<300 \mathrm{ppm})$, as well as the melt-zone olivine $(<400 \mathrm{ppm})$, which is evident in X-ray maps (Figure 7f). Chromium is compatible in orthopyroxene $\left(K_{D}=5.09\right.$; Foley et al., 2013$)$ relative to olivine ( $K_{D}=0.96$; Foley et al., 2013) and would concentrate in orthopyroxene in equilibrated mantle rocks. Indeed, orthopyroxene generally contains $\sim 3000$ ppm $\mathrm{Cr}$ in peridotite xenoliths (e.g., Gibson et al., 2008). Therefore, the assimilation of orthopyroxene by the early stage kimberlitic melts would result in significant increases in the $\mathrm{Cr}$ contents in the proto-kimberlite. We suggest that the transition zones observed on both the Type 1 and 2 cores were equilibrating with this early stage proto-kimberlite at the base of the lithosphere prior to transport to the surface, as also suggested by Cordier et al. (2015). Therefore, we suggest that orthopyroxene assimilation occurred at the base of the SCLM during kimberlite melt generation, and not en route to the surface, as suggested by Pilbeam et al. (2013) and Bussweiler et al. (2015).

\subsubsection{Fe-P-rich olivine: Rapid crystal-growth rate changes}

The Fe-P-rich trend is observed between the melt-zone and the rims, and represents a highly evolved kimberlite melt (Figure 3). Cordier et al. (2015) report olivines with similar Fo contents, but high $\mathrm{Ni}$ (2100-2500 ppm), which were observed adjacent to cores rather than at the margin. They interpreted the Fe-rich olivine composition to represent deep-seated interaction of kimberlite melt with basaltic melt. In the case of the Benfontein Fe-P-rich olivine, the Ni contents are low (<700 ppm) (Figure 3), indicating crystallisation at a late-stage after significant previous olivine crystallisation, toward the end of the melt-zone evolution stage. Compositional X-ray maps show a correlation between these zones and elevated P contents (Figure 7e). In recent studies, it has been shown that P-rich zones identified in olivine represent incorporation of excess $\mathrm{P}$ due to rapid growth, and zoning patterns record growth rate 
Howarth and Taylor - Zoned olivine from the Benfontein kimberlite, South Africa

510 variations (e.g., Milman-Barris et al., 2008). Therefore, in the case of the Fe-P-rich olivine zones in the

511 Benfontein kimberlite, the correlation with P-enrichment indicates a stage of rapid growth rate, and

512 rapid changes in growth rate in these zones.

513

514

515

516

517

518

519

520

521

522

523

524

525

526

527

528

529

530

531

532

533

534

535

536

537

538

539

540

\subsubsection{Late-stage evolution to Fe-poor carbonatitic melts}

The fine-grained rims on the olivines are characterised by an increases in Fo content; decreases in $\mathrm{Ni}, \mathrm{Co}$, and $\mathrm{Zn}$; and a sharp increase in $\mathrm{Ca}, \mathrm{Mn}, \mathrm{Sc}$, and Ti. This trend defines a second kimberlite melt evolutionary stage. Bussweiler et al. (2015) suggested that concurrent crystallisation of oxide minerals, in particular ilmenite, during the formation of olivine melt-zones results in significant depletion of the residual kimberlite in $\mathrm{FeO}$ and resultant increase in the Fo content of subsequent olivine, crystallising as fine-grained rims. Indeed, the presence of both chromite and Mg-ilmenite as inclusions within the olivine melt-zones is consistent with such an interpretation. However, the significant increase in Ti observed in the rims is not consistent with ilmenite crystallisation. Jones and Wyllie (1985) showed that the oxide phases in the Benfontein sill can be divided into two petrogenetic groups: 1) early macrocrysts and cores of chromite and Mg-ilmenite, and 2) late-stage rims and groundmass grains of Mg-Altitanomagnetite. The two groups are separated by reaction textures or carbonate and are characterised by a distinct gap in composition. These features were interpreted to represent early stage chromite crystallisation from the kimberlite, followed by late-stage crystallisation after a critical change in the role of $\mathrm{CO}_{2}$ species in the magma (Jones and Wyllie, 1985); this was likely related to the late-stage evolution of the Benfontein sill to carbonatitic compositions. The presence of Mg-Al-titanomagnetite associated with the rims of olivine in this study suggests that the late-stage Mg-rich rims may, similarly to the MgAl-titanomagnetite, be related to late-stage evolution of the kimberlite melt to carbonatitic compositions. This suggestion is also consistent with the sharp increase in Ca contents (up to $1 \mathrm{wt}$ \%) for the rims, including the formation of perovskite. Pilbeam et al. (2013) similarly interpreted high Fo, Ca-rich rims on olivines from the Majuagaa kimberlites (Greenland) to form through equilibration with late-stage carbonatitic liquids. They further suggested an $\mathrm{Mg \#}$ for the carbonatitic melt compositions of >95, which is consistent with an Mg\# of 94 for melts calculated to be in equilibrium (using a Fe-Mg exchange coefficient of 0.5), with the high Fo rims observed in this study. A similar Mg\# for late-stage melts was also calculated for Canadian examples by Bussweiler et al. (2015), implying that kimberlites worldwide evolve to Mg-rich carbonatitic compositions. Extremely Mg-rich olivine compositions in basaltic magmas have been suggested to be related to an increase in $\mathrm{fO}_{2}$ conditions, where the charge 


\section{Howarth and Taylor - Zoned olivine from the Benfontein kimberlite, South Africa}

541 imbalance results in less Fe being able to fit into the olivine crystal structure (e.g., Blondes et al., 2012).

542 This is also consistent with the late-stage oxide phase being Mg-Al-titanomagnetite with significantly

543 more ferric iron than earlier oxides, as well as the low $\mathrm{V} / \mathrm{Sc}$ value for the olivine rims, indicating

544 crystallisation from more oxidising conditions than the melt-zone. Therefore, a combination of Fe

545 depletion during oxide crystallisation and an increase in $\mathrm{fO}_{2}$ during late-stage evolution to carbonatitic

546 melts likely play a role in the evolution of the olivine rim compositions. This implies that the kimberlite

547 magma that potentially originated as a carbonatitic melt at the base of the SCLM prior to assimilation of

548 orthopyroxene evolves back to carbonatitic compositions at a late-stage at crustal depths. A similar

549 interpretation was made by Kamenetsky et al. (2008). This interpretation is consistent with the

550 carbonatitic character of the kimberlite of the Benfontein sill, as described by Dawson and Hawthorne

551 (1973).

\subsection{Model for kimberlite evolution from mantle to crust}

In the following section, we have summarized, with an illustrated model (Figure 10), our interpretations for the genesis and evolution of the Benfontein kimberlite parent melt from mantle to crust, which is applicable to kimberlites worldwide. Outlined here are six steps for the origin and evolution of kimberlite magmas tracked in zoned olivine from the Benfontein kimberlite sill.

Step 1) Alkali-rich carbonate-silicate melts derived from the deep mantle intrude the base of the lithosphere. Step 2) The melts initially form small vein stockworks at this depth and begin to interact with the surrounding peridotitic material, resulting in metasomatism and resultant increase in $\mathrm{Ca}, \mathrm{Na}$,

563 that described by Arndt et a. (2010), termed 'metasomatic defertilisation' occurring as an alteration halo 564 surrounding early stages of kimberlite melt intrusion at the base of the SCLM. At the same time orthopyroxene and other silicates are likely assimilated and dissolved into the evolving melt. The resultant residue is dunitic in composition; however, unlike typical mantle dunite produced by partial

567 melting/metasomatism by Fe-Ti-rich melts (e.g., Rehfeldt et al., 2007; 2008), the residual dunite 568 produced here has a Ca-rich metasomatic signature (Type 1 olivine cores). Step 3) As a result of the orthopyroxene assimilation, the melt now changes in composition, increasing in $\mathrm{MgO}$ and other trace

570 elements such as $\mathrm{Cr}$. This melt now forms pockets with sufficient volume to begin ascent through the 
571 lithosphere, entraining parts of both the defertilised dunite (Type 1 cores) and garnet peridotite (Type 2

572 cores). Entrained olivine xenocrysts then equilibrate with the proto-kimberlite producing the transition-

573 zone olivine, analysed in this study. This likely occurred at depth in the lithospheric mantle, as the melt

574 begins to ascend to the surface. Step 4) The kimberlite melt then begins rapid ascent to the surface. At

575 this stage, new olivine growth, represented by the melt-zone olivine, begins through nucleation on pre-

576 existing xenocrystic cores. Step 5) Through extensive olivine crystallisation, the kimberlite melt evolves

577 from initial ultramafic compositions to mafic compositions, crystallising the Fe-rich olivines zones. And

578 lastly, Step 6) Intrusion at crustal levels and further crystallisation of oxide and phosphate phases results

579 in late-stage evolution of the kimberlite melt to carbonatitic compositions, and the formation of the final 580 stage of olivine growth/equilibration in the form of high Fo rims.

581

Therefore, the complexly zoned olivines observed at the Benfontein sill effectively track the early

583 stages of kimberlite melt genesis within the mantle, as well as subsequent evolution of the melt en route 584 to the surface. The complex nature of the olivines highlights the hybrid complex history of kimberlite magmas and the need for further detailed work on olivines in kimberlites.

\section{Summary}

Olivines from the Benfontein kimberlite are some of the best preserved and reported in the

589 literature to date. They provide important evidence for the genesis and evolution of kimberlite magma

590 from mantle to crustal depths. Xenocrystic olivine cores have sources from two separate lithologies in

591 the mantle. We suggest that the Type 2 olivine cores are derived from a typical garnet peridotite mantle 592 lithology, similar to typical mantle xenoliths brought to the surface in the kimberlite magmas. The Type

5931 olivine cores represent a mantle source that has undergone metasomatism driven by a carbonate594 silicate melt at high temperature $\left(>1400^{\circ} \mathrm{C}\right)$. We suggest that the chemistry of the Type 1 olivine cores 595 represents direct evidence for this early stage melt in the kimberlite magma generation process, and 596 represent possible antecrysts directly related to the kimberlite plumbing-system. The first evidence for 597 such antecrysts in kimberlite magmas was presented by Giuliani et al. (2016) for rims of phlogopite 598 macrocrysts in the Bultfontein kimberlite. This further suggests that the metasomatism accompanied by 599 the intrusion of these melts occurred prior to extensive orthopyroxene assimilation and resultant 600 formation of the kimberlite magma that ascends to the surface. This interpretation favours the 
601 hypothesis of Arndt et al. (2010) for 'metasomatic defertilisation' of the mantle by invading $\mathrm{CO}_{2}$-rich

602 melts and resultant development of a proto-kimberlitic melt at the base of the lithosphere.

603

604

605

606

607

608

609

610

611

612

613

614

615

616

617

618

619

620

621

622

623

624

625

626

627

628

629

630

The melt-zone olivines represent the evolution of the kimberlite melt and provide additional constraints on kimberlite evolution. We infer that the melt-zone olivine represents continued olivine crystallisation and evolution of the kimberlite magma en route from mantle source to surface. Furthermore, we suggest that the increased $\mathrm{Cr}$ contents observed for equilibration transition-zone olivine indicates an increase in $\mathrm{Cr}$ contents of the initial proto-kimberlite magma, due to the assimilation of orthopyroxene at the base of the SCLM, prior to transport to the surface.

We present a complex model for kimberlite melt genesis and evolution, beginning as a carbonatesilicate melt, intruding the base of the lithosphere. Initial 'metasomatic defertilisation' results in a metasomatic dunite lithology immediately surrounding the carbonate-silicate melt pocket. Due to this metasomatism and orthopyroxene assimilation, the melt evolves into the kimberlite melt. This melt then incorporates olivine from both the metasomatised dunite, as well as typical peridotitic mantle lithologies. These olivines equilibrate with the $\mathrm{Cr}$-rich kimberlite melt and begin ascent to the surface. The kimberlite melt then crystallises olivine, through nucleation on the xenocrystic olivines. Olivine crystallisation continues from mantle to crustal levels and terminates with faster cooling and rapid crystal growth of Fe-P-rich olivine compositions. The kimberlite melt then begins to crystallise oxide and phosphate phases with further evolution to carbonatitic melts that equilibrate with the olivines producing fine margins of Mg-rich olivines.

\section{Acknowledgements}

We would like to thank Christel Tinguely for assistance on Electron Microprobe and Laser Ablation data collection at the University of Cape Town. Additionally, we would like to thank Allan Patchen for aid in X-ray map data collection from the Electron Microprobe at the University of Tennessee. The senior author $(\mathrm{GHH})$ would like to acknowledge post-doctoral research funding from the Claude Leon foundation and the URC funding program at University of Cape Town. Additional support for analytical costs was provided by Chris Harris through his National Research Foundation (RSA) incentive fund. A portion of this study was made possible by a National Science Foundation (USA) Grants 

manuscript.

\section{References}

Agashev, A. M., Ionov, D. A., Pokhilenko, N. P., Golovin, A. V., Cherepanova, Y., Sharygin, I. S. 2013. Metasomatism peridotite xenoliths from kimberlite pipe Udachnaya. Lithos 160, 201-215.

Brett, R.C., Russell, J.K., Moss, S. 2009. Origin of olivine in kimberlite: Phenocryst or impostor? Lithos 112, 201-212.

650

651

652

653

654

655

656

Bussweiler, Y., Stone, R. S., Pearson, D. G., Luth, R. W., Stachel, T., Kjarsgaard, B. A., Menzies, A. 2016. The evolution of calcite-bearing kimberlites by melt-rock reaction: evidence from polymineralic inclusions within clinopyroxene and garnet megacrysts from Lac de Gras kimberlites, Canada. Contributions to Mineralogy and Petrology 171, 1-25.

Bussweiler, Y., Foley, S.F., Prelević, D., Jacob, D.E. 2015. The olivine macrocryst problem: New insights from minor and trace element compositions of olivine from Lac de Gras kimberlites, Canada. Lithos 220, 238-252.

Carswell, D.A., Clarke, D.B., Mitchell, R. H. 1979. The petrology and geochemistry of ultramafic nodules from Pipe 200, northern Lesotho. The Mantle Sample: Inclusion in Kimberlites and Other Volcanics 127-144.
Clement, C.R., Skinner, E.M.W. 1985. A textural-genetic classification of kimberlites. South African Journal of Geology 88, 403-409.

Cordier, C., Sauzeat, L., Arndt, N.T., Boullier, A.M., Batanova, V., Barou, F. 2015. Metasomatism of the lithospheric mantle immediately precedes kimberlite eruption: New evidence from olivine composition and microstructures. Journal of Petrology 56, 1775-1796. 


\section{Howarth and Taylor - Zoned olivine from the Benfontein kimberlite, South Africa}

Dalton, J. A., Wood, B. J. 1993. The partitioning of Fe and Mg between olivine and carbonate and the stability of carbonate under mantle conditions. Contributions to Mineralogy and Petrology 114, 501-509.

Dawson, J.B., Hawthorne, J.B. 1973. Magmatic sedimentation and carbonatitic differentiation in kimberlite sills at Benfontein, South Africa. Journal of the Geological Society 129, 61-85.

De Hoog, J.C., Gall, L., Cornell, D.H. 2010. Trace-element geochemistry of mantle olivine and application to mantle petrogenesis and geothermobarometry. Chemical Geology 270, 196-215.

Foley, S.F., Prelevic, D., Rehfeldt, T., Jacob, D.E. 2013. Minor and trace elements in olivines as probes into early igneous and mantle melting processes. Earth and Planetary Science Letters 363, 181-191.

Foley, S.F., Andronikov, A.V., Jacob, D.E., Melzer, S. 2006. Evidence from Antarctic mantle peridotite xenoliths for changes in mineralogy, geochemistry and geothermal gradients beneath a developing rift. Geochimica et Cosmochimica Acta 70, 3096-3120.

Gibson, S.A., Malarkey, J., Day, J.A. 2008. Melt depletion and enrichment beneath the western Kaapvaal Craton: evidence from Finsch peridotite xenoliths. Journal of Petrology 49, 1817-1852.

Giuliani, A., Kamenetsky, V.S., Phillips, D., Kendrick, M.A., Wyatt, B.A., Goemann, K. 2012. Nature of alkalicarbonate fluids in the sub-continental lithospheric mantle. Geology 40, 967-970.

Giuliani, A., Kamenetsky, V.S., Kendrick, M.A., Phillips, D., Wyatt, B.A., Maas, R. 2013. Oxide, sulphide and carbonate minerals in a mantle polymict breccia: Metasomatism by proto-kimberlite magmas, and relationship to the kimberlite megacrystic suite. Chemical Geology 353, 4-18.

Giuliani, A., Phillips, D., Kamenetsky, V.S., Kendrick, M.A., Wyatt, B.A., Goemann, K., Hutchinson, G. 2014. Petrogenesis of mantle polymict breccias: insights into mantle processes coeval with kimberlite magmatism. Journal of Petrology 55, 831-858.

Giuliani, A., Phillips, D., Kamenetsky, V. S., Goemann, K. 2016. Constraints on kimberlite ascent mechanisms revealed by phlogopite compositions in kimberlites and mantle xenoliths. Lithos 240, 189-201.

Griffin, W.L., Shee, S.R., Ryan, C.G., Win, T.T., Wyatt, B.A. 1999. Harzburgite to Iherzolite and back again: metasomatic processes in ultramafic xenoliths from the Wesselton kimberlite, Kimberley, South Africa. Contributions to Mineralogy and Petrology 134, 232-250.

Gurney, J.J., Jakob, W.R.O., Dawson, J.B. 1979. Megacrysts from the Monastery kimberlite pipe, South Africa. The Mantle Sample: Inclusion in Kimberlites and Other Volcanics, 227-243. 


\section{Howarth and Taylor - Zoned olivine from the Benfontein kimberlite, South Africa}

Harte, B., Winterburn, P.A., Gurney, J.J. 1987. Metasomatic and enrichment phenomena in garnet peridotite facies mantle xenoliths from the Matsoku kimberlite pipe, Lesotho. Mantle metasomatism. Academic Press, London, 145220.

Hervig, R. L., Smith, J. V., Dawson, J. B. 1986. Lherzolite xenoliths in kimberlites and basalts: petrogenetic and crystallochemical significance of some minor and trace elements in olivine, pyroxenes, garnet and spinel. Transactions of the Royal Society of Edinburgh: Earth Sciences 77, 181-201.

Howarth, G. H., Barry, P. H., Pernet-Fisher, J. F., Baziotis, I. P., Pokhilenko, N. P., Pokhilenko, L. N., Taylor, L.A., Agashev, A. M. 2014. Superplume metasomatism: Evidence from Siberian mantle xenoliths. Lithos 184, 209-224.

Jones, A.P., Wyllie, P.J. 1985. Paragenetic trends of oxide minerals in carbonate-rich kimberlites, with new analyses from the Benfontein Sill, South Africa. Journal of Petrology 26, 210-222.

Kaeser, B., Kalt, A., Pettke, T. 2006. Evolution of the lithospheric mantle beneath the Marsabit volcanic field (northern Kenya): constraints from textural, P-T and geochemical studies on xenoliths. Journal of Petrology 47, 2149-2184.

Kamenetsky, V.S., Yaxley, G.M. 2015. Carbonate-silicate liquid immiscibility in the mantle propels kimberlite magma ascent. Geochimica et Cosmochimica Acta 158, 48-56.

Kamenetsky, V.S., Kamenetsky, M.B., Sobolev, A.V., Golovin, A.V., Demouchy, S., Faure, K., Kuzmin, D. V. 2008. Olivine in the Udachnaya-East kimberlite (Yakutia, Russia): types, compositions and origins. Journal of Petrology 49, 823-839.

Kamenetsky, M.B., Sobolev, A.V., Kamenetsky, V.S., Maas, R., Danyushevsky, L.V., Thomas, R., Sobolev, N.V. 2004. Kimberlite melts rich in alkali chlorides and carbonates: a potent metasomatic agent in the mantle. Geology 32 , 845-848.

Lazarov, M., Woodland, A.B., Brey, G. P. 2009. Thermal state and redox conditions of the Kaapvaal mantle: a study of xenoliths from the Finsch mine, South Africa. Lithos 112, 913-923.

Le Roex, A.P., Bell, D.R., Davis, P. 2003. Petrogenesis of group I kimberlites from Kimberley, South Africa: evidence from bulk-rock geochemistry. Journal of Petrology 44, 2261-2286.

Hanson, E.K., Moore, J.M., Bordy, E.M., Marsh, J.S., Howarth, G., Robey, J.V.A. 2009. Cretaceous erosion in central South Africa: Evidence from upper-crustal xenoliths in kimberlite diatremes. South African Journal of Geology 112 , 125-140. 


\section{Howarth and Taylor - Zoned olivine from the Benfontein kimberlite, South Africa}

Marsh, J.S., Hooper, P.R., Rehacek, J.J., Duncan, R.A., Duncan, A. R. 1997. Stratigraphy and age of Karoo basalts of Lesotho and implications for correlations within the Karoo igneous province. Large igneous provinces: continental, oceanic, and planetary flood volcanism, 247-272.

McGetchin, T.R., Nikhanj, Y.S., Chodos, A.A. 1997. Carbonatite-kimberlite relations in the Cane Valley Diatreme, San Juan County, Utah. Journal of Geophysical Research 78, 1854-1869.

Mitchell, R.H. 2008. Petrology of hypabyssal kimberlites: relevance to primary magma compositions. Journal of Volcanology and Geothermal Research 174, 1-8.

Mitchell, R.H. 1970. Kimberlite and Related Rocks: A Critical Reappraisal. The Journal of Geology 686-704.

Moore, A.E. 2012. The case for a cognate, polybaric origin for kimberlitic olivines. Lithos 128, 1-10.

Moore, A.E. 1988. Olivine: a monitor of magma evolutionary paths in kimberlites and olivine melilitites. Contributions to Mineralogy and Petrology 99, 238-248.

Neumann, E.R., Wulff-Pedersen, E., Pearson, N.J., Spencer, E.A. 2002. Mantle xenoliths from Tenerife (Canary Islands): evidence for reactions between mantle peridotites and silicic carbonatite melts inducing $\mathrm{Ca}$ metasomatism. Journal of Petrology 43, 825-857.

Pilbeam, L.H., Nielsen, T.F.D., Waight, T.E. 2013. Digestion fractional crystallization (DFC): an important process in the genesis of kimberlites. Evidence from olivine in the Majuagaa kimberlite, southern West Greenland. Journal of Petrology 54, 1399-1425.

Priestley, K., McKenzie, D., Debayle, E. 2006. The state of the upper mantle beneath southern Africa. Tectonophysics 416, 101-112.

Russell, J.K., Porritt, L.A., Lavallée, Y., Dingwell, D.B. 2012. Kimberlite ascent by assimilation-fuelled buoyancy. Nature 481, 352-356.

Seitz, H.M., Woodland, A.B. 2000. The distribution of lithium in peridotitic and pyroxenitic mantle lithologies - an indicator of magmatic and metasomatic processes. Chemical Geology 166, 47-64.

Simon, N.S., Carlson, R.W., Pearson, D.G., Davies, G.R. 2007. The origin and evolution of the Kaapvaal cratonic lithospheric mantle. Journal of Petrology 48, 589-625.

Soltys, A., Giuliani, A., Phillips, D., Kamenetsky, V. S., Maas, R., Woodhead, J., Rodemann, T. 2016. In-situ assimilation of mantle minerals by kimberlitic magmas-Direct evidence from a garnet wehrlite xenolith entrained in the Bultfontein kimberlite (Kimberley, South Africa). Lithos 256, 182-196. 
Howarth and Taylor - Zoned olivine from the Benfontein kimberlite, South Africa

788

789 Sparks, R.S.J. 2013. Kimberlite volcanism. Annual Review of Earth and Planetary Sciences 41, 497-528.

790

791 Woodland, A.B., Koch, M. 2003. Variation in oxygen fugacity with depth in the upper mantle beneath the Kaapvaal

792 craton, Southern Africa. Earth and Planetary Science Letters 214, 295-310.

793

794

795

796

797

798

799

800

801

802

803

804

805

806

807

808

809

810

811

812

813

814

815

816

817

818

819 
820 Table 1. Representative Electron Microprobe analyses of olivine from Type 1 (T1) and Type 2 (T2) cores 821 as well as transition zone, melt zone, Fe-P-rich melt, and rims.

822

\begin{tabular}{|c|c|c|c|c|c|c|c|c|c|c|}
\hline & $\begin{array}{c}\text { T1 } \\
\text { Core }\end{array}$ & $\begin{array}{c}\text { T2 } \\
\text { Core }\end{array}$ & $\begin{array}{c}\text { T1 } \\
\text { Transition } \\
\end{array}$ & $\begin{array}{c}\text { T2 } \\
\text { Transition } \\
\end{array}$ & Melt & Melt & $\begin{array}{l}\text { Ee-P-rich } \\
\text { Melt }\end{array}$ & $\operatorname{Rim}$ & Rim & Rim \\
\hline $\mathrm{SiO}_{2}$ & 40.2 & 41.1 & 40.3 & 40.7 & 40.6 & 40.4 & 40.3 & 40.8 & 40.7 & 42.0 \\
\hline $\mathrm{MgO}$ & 47.9 & 50.5 & 48.2 & 48.5 & 47.7 & 47.9 & 46.0 & 49.3 & 50.9 & 53.6 \\
\hline $\mathrm{TiO}_{2}$ & 0.02 & - & 0.03 & 0.03 & 0.04 & 0.04 & 0.05 & 0.03 & 0.06 & 0.02 \\
\hline $\mathrm{CaO}$ & 0.08 & 0.06 & 0.07 & 0.06 & 0.09 & 0.07 & 0.12 & 0.21 & 0.32 & 0.74 \\
\hline $\mathrm{Al}_{2} \mathrm{O}_{3}$ & 0.05 & 0.04 & 0.03 & 0.01 & 0.01 & 0.01 & 0.01 & 0.02 & 0.03 & $<0.01$ \\
\hline $\mathrm{Cr}_{2} \mathrm{O}_{3}$ & 0.04 & 0.06 & 0.03 & 0.07 & 0.03 & 0.03 & - & 0.01 & - & 0.01 \\
\hline $\mathrm{FeO}$ & 11.2 & 6.83 & 10.4 & 8.98 & 10.1 & 9.92 & 14.4 & 8.58 & 5.78 & 2.35 \\
\hline $\mathrm{MnO}$ & 0.13 & 0.12 & 0.16 & 0.15 & 0.19 & 0.17 & 0.29 & 0.28 & 0.33 & 0.46 \\
\hline $\mathrm{NiO}$ & 0.33 & 0.32 & 0.33 & 0.32 & 0.21 & 0.16 & 0.05 & $<0.01$ & 0.02 & 0.02 \\
\hline $\mathrm{P}_{2} \mathrm{O}_{5}$ & 0.01 & $<0.01$ & 0.03 & 0.03 & 0.03 & 0.02 & 0.07 & 0.04 & 0.07 & 0.01 \\
\hline Total & 99.9 & 99.0 & 99.5 & 98.9 & 99.0 & 98.7 & 101.2 & 99.3 & 98.2 & 99.2 \\
\hline $\mathrm{Mg}$ & 1.765 & 1.841 & 1.775 & 1.787 & 1.763 & 1.774 & 1.695 & 1.803 & 1.863 & 1.912 \\
\hline $\mathrm{Ti}$ & 0.000 & 0.000 & 0.000 & 0.000 & 0.001 & 0.001 & 0.001 & 0.001 & 0.001 & 0.000 \\
\hline $\mathrm{Ca}$ & 0.002 & 0.002 & 0.002 & 0.002 & 0.002 & 0.002 & 0.003 & 0.005 & 0.008 & 0.019 \\
\hline $\mathrm{Al}$ & 0.001 & 0.001 & 0.001 & 0.000 & 0.000 & 0.000 & 0.000 & 0.001 & 0.001 & 0.000 \\
\hline $\mathrm{Cr}$ & 0.001 & 0.001 & 0.001 & 0.001 & 0.001 & 0.001 & 0.000 & 0.000 & 0.000 & 0.000 \\
\hline $\mathrm{Fe}$ & 0.231 & 0.140 & 0.215 & 0.185 & 0.209 & 0.206 & 0.297 & 0.176 & 0.119 & 0.047 \\
\hline $\mathrm{Mn}$ & 0.003 & 0.002 & 0.003 & 0.003 & 0.004 & 0.004 & 0.006 & 0.006 & 0.007 & 0.009 \\
\hline $\mathrm{Si}$ & 0.994 & 1.003 & 0.997 & 1.006 & 1.006 & 1.004 & 0.996 & 1.003 & 0.998 & 1.005 \\
\hline $\mathrm{Ni}$ & 0.007 & 0.006 & 0.007 & 0.006 & 0.004 & 0.003 & 0.001 & 0.000 & 0.000 & 0.000 \\
\hline$P$ & 0.000 & 0.000 & 0.001 & 0.001 & 0.001 & 0.000 & 0.002 & 0.001 & 0.002 & 0.000 \\
\hline SUM & 3.00 & 3.00 & 3.00 & 2.99 & 2.99 & 2.99 & 3.00 & 3.00 & 3.00 & 2.99 \\
\hline Fo & 88.4 & 93.0 & 89.2 & 90.6 & 89.4 & 89.6 & 85.1 & 91.1 & 94.0 & 97.6 \\
\hline
\end{tabular}

823

824

825

826

827

828

829

830

831

832 
Howarth and Taylor - Zoned olivine from the Benfontein kimberlite, South Africa

Table 2. Laser Ablation ICP-MS data for olivines analysed from the Benfontein macrocrystic kimberlite.

\begin{tabular}{|c|c|c|c|c|c|c|c|c|c|c|c|c|c|}
\hline & Li & $\mathrm{Na}$ & Al & $\mathrm{Ca}$ & Sc & $\mathrm{Ti}$ & V & $\mathrm{Cr}$ & $\mathrm{Mn}$ & Co & $\mathbf{N i}$ & $\mathrm{Cu}$ & $\mathrm{Zn}$ \\
\hline Type 1 core & 1.77 & 188 & 238 & 548 & 2.59 & 110 & 6.78 & 287 & 794 & 140 & 2761 & 3.93 & 73.0 \\
\hline Type 1 core & 4.35 & 557 & 658 & 750 & 2.93 & 82.3 & 11.3 & 219 & 814 & 150 & 2595 & 6.11 & 88.7 \\
\hline Type 1 core & 2.92 & - & 559 & 763 & 2.70 & 90.2 & 11.8 & 229 & 805 & 149 & 2687 & 5.67 & 93.1 \\
\hline Type 1 core & 2.60 & 323 & 375 & 588 & 2.46 & 106 & 10.1 & 121 & 822 & 164 & 2241 & 5.88 & 96.8 \\
\hline Type 1 core & 3.91 & 470 & 515 & 776 & 2.62 & 92.3 & 9.89 & 418 & 773 & 143 & 2768 & 5.76 & 82.5 \\
\hline Type 1 core & 3.22 & 488 & 530 & 650 & 2.41 & 96.8 & 10.3 & 451 & 783 & 140 & 2813 & 5.85 & 79.9 \\
\hline Type 1 core & 2.47 & 382 & 489 & 794 & 2.57 & 139 & 11.6 & 250 & 795 & 150 & 2661 & 6.64 & 94.0 \\
\hline Type 1 core & 2.69 & 331 & 428 & 643 & 2.51 & 99.0 & 11.0 & 95 & 835 & 166 & 2017 & 5.00 & 98.1 \\
\hline Type 1 core & 2.67 & 242 & 1928 & 1002 & 2.77 & 211 & 12.6 & 440 & 899 & 141 & 2754 & 4.83 & 60.9 \\
\hline Type 1 core & 2.12 & 345 & 455 & 796 & 2.45 & 110 & 10.4 & 262 & 783 & 141 & 2756 & 5.16 & 79.3 \\
\hline Type 1 core & 2.67 & 369 & 562 & 1479 & 2.84 & 127 & 5.82 & 554 & 815 & 136 & 2731 & 5.36 & 64.4 \\
\hline Type 2 core & 1.99 & 115 & 198 & 422 & 2.02 & 105 & 5.71 & 218 & 696 & 126 & 2896 & 3.19 & 53.2 \\
\hline Type 2 core & 2.36 & 210 & 291 & 587 & 2.16 & 122 & 6.25 & 370 & 656 & 111 & 2525 & 5.08 & 49.6 \\
\hline Type 2 core & 1.29 & 141 & 133 & 466 & 4.10 & 51.8 & 5.13 & 170 & 594 & 125 & 2855 & 2.48 & 47.7 \\
\hline Type 2 core & 1.49 & 109 & 108 & 405 & 3.49 & 47.4 & 5.07 & 194 & 642 & 125 & 2879 & 1.82 & 54.1 \\
\hline Type 2 core & 1.59 & 133 & 171 & 516 & 3.04 & 77.0 & 5.71 & 190 & 682 & 129 & 2865 & 2.42 & 49.5 \\
\hline Type 2 core & 1.73 & 44.9 & 38.4 & 138 & 2.30 & 26.0 & 3.08 & 54 & 684 & 141 & 3197 & 0.60 & 57.0 \\
\hline Type 2 core & 1.63 & 59.4 & 66.5 & 361 & 2.69 & 42.2 & 3.50 & 66 & 705 & 142 & 3147 & 1.26 & 57.2 \\
\hline Type 2 core & 1.72 & 125 & 129 & 248 & 2.25 & 138 & 4.52 & 247 & 699 & 114 & 2500 & 2.32 & 54.8 \\
\hline Type 2 core & 2.05 & 158 & 130 & 532 & 3.00 & 146 & 4.73 & 181 & 776 & 140 & 2434 & 2.50 & 69.4 \\
\hline Type 2 core & 1.64 & 119 & 107 & 240 & 2.37 & 153 & 4.62 & 251 & 738 & 118 & 2576 & 2.13 & 53.9 \\
\hline Transition & 2.63 & 235 & 240 & 652 & 3.71 & 113 & 5.25 & 519 & 592 & 136 & 2941 & 4.25 & 65.8 \\
\hline Transition & 2.34 & 182 & 217 & 678 & 3.87 & 112 & 6.00 & 393 & 720 & 141 & 3122 & 4.25 & 71.1 \\
\hline Transition & 1.91 & 167 & 186 & 553 & 2.38 & 97.8 & 4.43 & 435 & 711 & 137 & 2973 & 4.15 & 63.5 \\
\hline Transition & 2.12 & 151 & 175 & 540 & 2.40 & 99.3 & 4.56 & 394 & 795 & 140 & 3061 & 3.94 & 63.4 \\
\hline Transition & 1.78 & 153 & 197 & 563 & 2.06 & 108 & 4.33 & 380 & 785 & 138 & 3040 & 4.01 & 61.5 \\
\hline Melt & 2.03 & 129 & 155 & 956 & 4.07 & 180 & 3.51 & 212 & 1108 & 148 & 1922 & 2.56 & 70.3 \\
\hline Melt & 2.33 & 64.9 & 169 & 1089 & 6.25 & 228 & 2.71 & 187 & 1252 & 136 & 1040 & 1.80 & 68.0 \\
\hline Melt & 2.65 & 77.4 & 149 & 792 & 5.05 & 203 & 3.75 & 292 & 1130 & 144 & 1463 & 2.73 & 69.3 \\
\hline Melt & 1.35 & 90.8 & 244 & 1645 & 3.95 & 271 & 2.85 & 198 & 1015 & 134 & 1147 & 2.83 & 62.0 \\
\hline Melt & 2.23 & 122 & 184 & 524 & 2.52 & 143 & 5.85 & 378 & 828 & 142 & 2528 & 3.65 & 67.2 \\
\hline Melt & 2.14 & 79.8 & 210 & 925 & 3.35 & 236 & 4.14 & 529 & 705 & 141 & 1395 & 2.87 & 69.1 \\
\hline Melt & 2.19 & 190 & 186 & 1035 & 2.53 & 112 & 4.55 & 392 & 815 & - & - & - & 3.65 \\
\hline Melt & 1.91 & 467 & 1545 & 1457 & 3.44 & 215 & 7.75 & 587 & 762 & 134 & 1352 & 9.68 & 68.6 \\
\hline Melt & 1.73 & 74.1 & 151 & 921 & 3.63 & 188 & 3.02 & 243 & 826 & 137 & 1364 & 2.42 & 66.3 \\
\hline Melt & 2.30 & 86.8 & 220 & - & 2.57 & 125 & 4.51 & 311 & 908 & 146 & 2255 & 3.35 & 70.4 \\
\hline Melt & 1.97 & 150 & 171 & 1375 & 3.26 & 178 & 2.76 & 224 & 938 & 137 & 1499 & 2.74 & 64.1 \\
\hline Melt & 2.08 & 65.6 & 106 & 665 & 2.60 & 147 & 2.82 & 228 & 842 & 142 & 1860 & 2.12 & 65.7 \\
\hline $\operatorname{Rim}$ & 1.93 & 235 & 2283 & 7610 & 54.7 & 513 & 4.41 & 5.56 & 2244 & 75.3 & 89 & 3.58 & 86.2 \\
\hline Rim & 1.63 & 72.4 & 1010 & 5974 & 27.6 & 683 & 5.36 & 19.3 & 1752 & 91.4 & 281 & 0.95 & 53.2 \\
\hline Rim & 1.99 & $\begin{array}{l}218 \\
132\end{array}$ & 1855 & 4029 & 21.4 & 379 & 4.05 & 8.85 & 1579 & 87.5 & 289 & 5.13 & 63.3 \\
\hline Rim & 2.11 & 7 & 9509 & 4487 & 14.3 & 267 & 6.13 & 55.5 & 1323 & 113 & 649 & 3.73 & 62.5 \\
\hline Rim & 1.45 & 82.6 & 367 & 5204 & 31.3 & 541 & 1.17 & 2.29 & 1846 & 83.3 & 138 & 1.10 & 50.3 \\
\hline Rim & 1.36 & 312 & 767 & - & 16.5 & 635 & 4.53 & 15.0 & 1560 & 95.4 & 353 & 3.47 & 56.7 \\
\hline Rim & 2.09 & 145 & 2004 & 7485 & 39.4 & 905 & 5.22 & 5.00 & 1929 & 69.0 & 123 & 2.16 & 46.9 \\
\hline Rim & 1.22 & 124 & 350 & 2767 & 17.6 & 329 & 1.71 & 2.89 & 1431 & 97.7 & 346 & 1.14 & 52.2 \\
\hline
\end{tabular}




\section{Howarth and Taylor - Zoned olivine from the Benfontein kimberlite, South Africa}

834

835

836

837

838

839

840

841

842

843

844

845

846

847

848

849

850

851

852

853

854

855

856

857

858

859

860

861

862

863

864

865

866

867

868

869

870

871

\section{Figure Captions}

Figure 1. Map of the Kimberley region (South Africa) showing the distribution of kimberlite pipes and the location of the Benfontein sill complex.

Figure 2. Backscattered Electron (BSE) images and cross-polar photomicrographs of olivines from the Benfontein macrocrystic kimberlite, illustrating the difference between the Type 1 (T1) and Type 2 (T2) olivines described in this study. a) - b) Type 1 (T1) olivine grain characterised by low Fo ( 88) core with a higher Fo ( 91) transition zone. c) - d) Type 2 (T2) olivine grain with a distinct high Fo (92-94) with a lower Fo ( 91) transition zone. Note that the photomicrographs clearly show that both Type 1 and 2 olivine grains are polycrystalline in these examples. This is not true of all olivine, however, and both Type 1 and Type 2 olivines are also observed as single olivine crystals. e) and f) Images of a distinct polycrystalline olivine or 'dunite nodule' as referred to by Arndt et al. (2010). Note the lower Fo ( 88) melt-zone cross-cuts the individual olivine grains, indicating that this is a diffusive equilibration zone, rather than crystallisation of new olivine.

Figure 3. Forsterite (Fo) content versus $\mathrm{NiO}$ (wt.\%) for all olivine analyses from the Benfontein macrocrystic kimberlite. Fields for peridotite xenoliths after Carswell et al. (1979; Simon et al. (2010), and De Hoog et al. (2010). In addition, fields for olivine megacrysts analysed from the Monastery kimberlite after Gurney et al. (1979) are also illustrated for comparison.

Figure 4. Backscattered electron (BSE) images and compositional traverses across Type 1 olivines. a) Olivine \#1 showing multiple zones from an inner core, transition zone (TZ), two melt-zones and two distinct rims. b) Olivine \#3 showing similar zonation from an inner low Fo core to outer Fe-rich melt zones and high Fo rims.

Figure 5. Backscattered electron (BSE) images and compositional traverses across Type 2 olivines. a) Olivine \#2 showing multiple zones from an inner high Fo core, one distinct mantle and two distinct rims. b) Olivine \#8 showing similar zonation from an inner high Fo core to an outer Fe-rich and high Fo rims.

Figure 6. X-ray elemental maps for two representative olivine grains from the Benfontein kimberlite. a) b) Mg Ka maps showing the presence of distinct Mg-rich, high Fo rims. These rims are often partially serpentinised ( $T Z$ = transition zone' $\mathrm{MZ}=$ Melt zone). $\mathrm{c}$ ) $-\mathrm{d}$ ) Fe Ka maps showing the distinct zoning in the olivines. Note the very high Fe zone in $\mathrm{c}$ ), which is the basaltic composition described in the text. e) $\mathrm{P}$ $\mathrm{K} \alpha$ map for the olivine in a) and c). Note the presence of a distinct high $\mathrm{P}$ melt-zone associated with the Fe-rich basaltic zone described in c). f) $\mathrm{Cr} \mathrm{K} \alpha$ map showing an enrichment in $\mathrm{Cr}$ contents associated with the transition zone (TZ) olivine and low $\mathrm{Cr}$ contents in the melt trend and rim. 
872 Figure 7. Nickel versus trace element concentrations for all olivines analysed in this study. Symbol 873 legend is given in (b). Note that the Type 1 (T1) and Type 2 (T2) olivines cores are clearly distinct in trace 874 element concentrations; in particular, $\mathrm{Co}, \mathrm{Ca}, \mathrm{Al}$, and $\mathrm{Na}$.

Figure 8. a) Al (ppm) versus $\mathrm{Mn}$ (ppm) for Type 1 and 2 olivine cores, as well as the transition-zone olivine with the lithological classification fields from De Hoog et al. (2010). b) Ti (ppm) versus Ca (ppm) for the Type 1 and 2 cores, as well as the transition-zone olivines. Fields for Kaapvaal metasomatised and Kaapvaal peridotites are from De Hoog et al. (2010) and the dataset of Foley et al. (2013). The metasomatic trends from Kaapvaal craton metasomatism and metasomatism associated with riftrelated and Ocean Island xenoliths are from Foley et al. (2013). c) Ni (ppm) versus V/Sc for all olivines analysed in this study. Note the distinct difference on the Type 1 and Type 2 cores. Symbols are the same as those in Figure 7.

Figure 9. Aluminum in olivine thermometer for the Type 1 and Type 2 olivine cores at assumed pressure of $40,50,60$, and 70 kbar. The Al thermometer is that presented by De Hoog et al. (2010). It is clear that the Type 1 olivines have undergone high temperature disturbance resulting in temperatures higher than the typical geotherm for the Kaapvaal craton. In contrast, the Type 2 cores represent typical mantle temperatures, consistent with an interpretation of a garnet peridotite source.

Figure 10. Schematic illustration showing the genesis and evolutionary stages of kimberlite melt for the Benfontein kimberlite. Formation of the proto-kimberlite and metasomatic defertilisation are occurring concurrently. Metasomatic defertilisation results in the assimilation of orthopyroxene and resultant residual metasomatic dunite surrounding the kimberlite intrusion. The proto-kimberlite melt is the result of the assimilation of orthopyroxene by the carbonate-silicate melt. The rapid rise of the kimberlite melt to the crust is accompanied by the crystallisation of the melt-zone olivine. In the uppercrust, the final stages of kimberlite evolution back to carbonatitic melts are associated with the development of the high Fo olivine rims. 
Figure 1

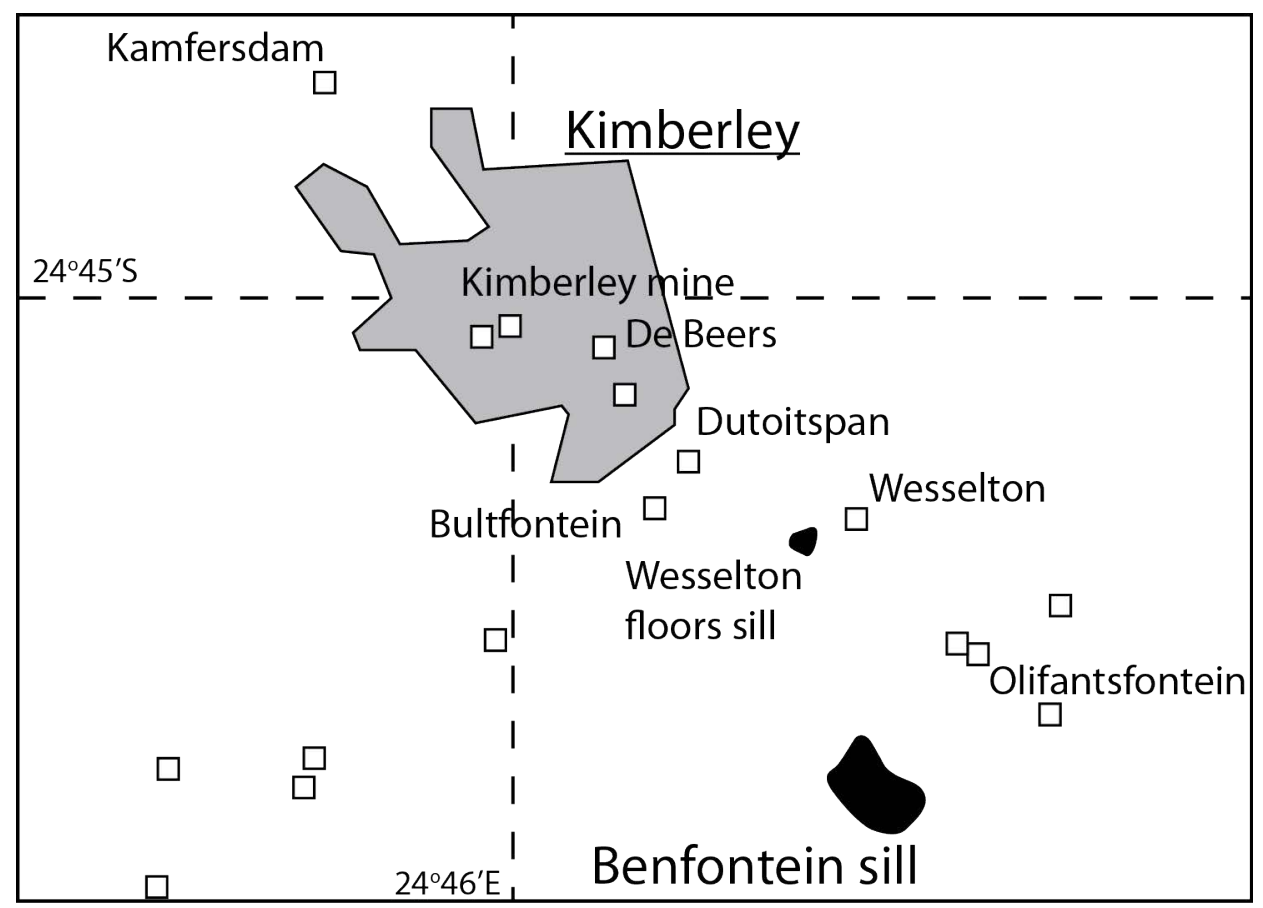




\section{Figure 2}
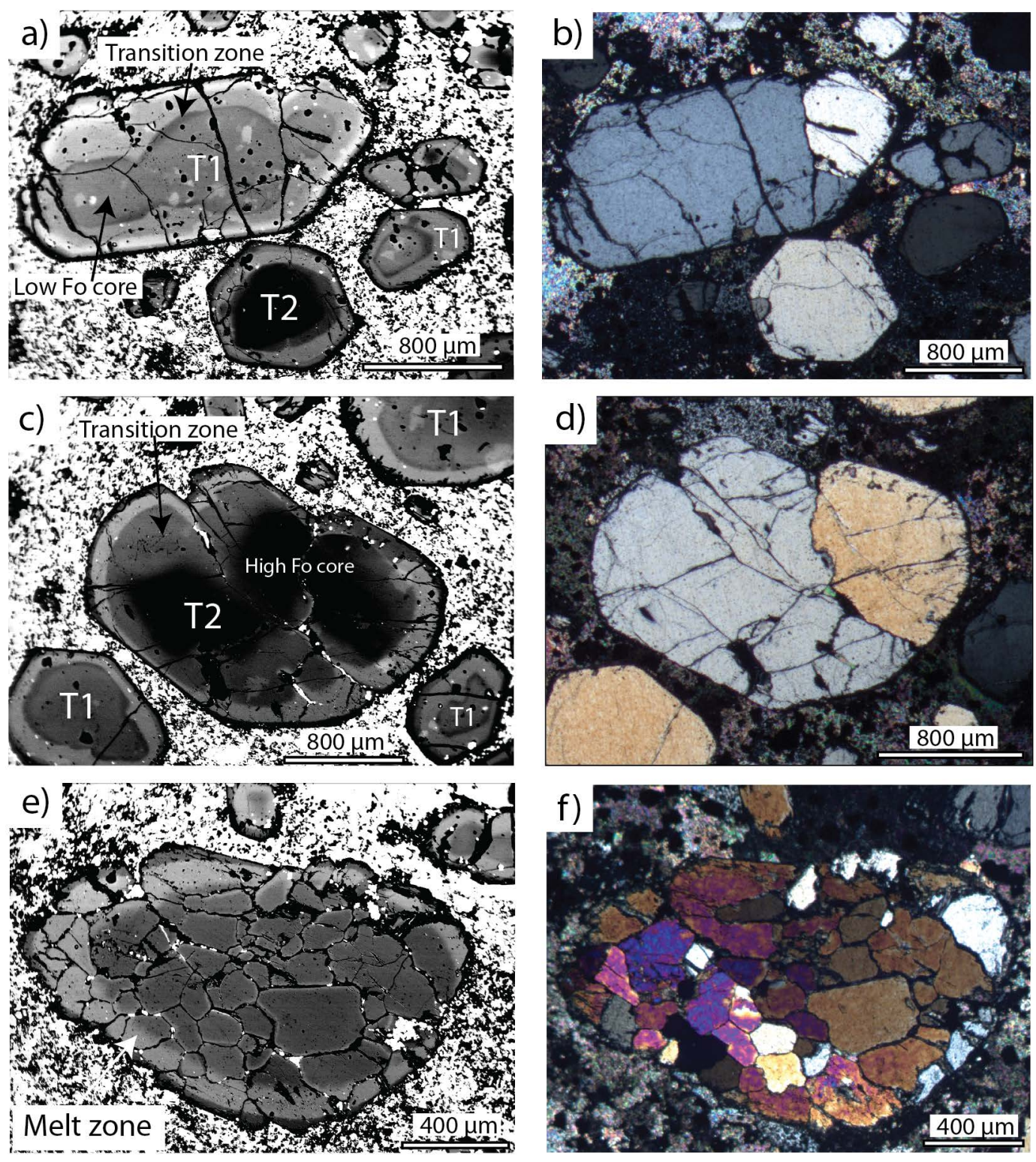
Figure 3

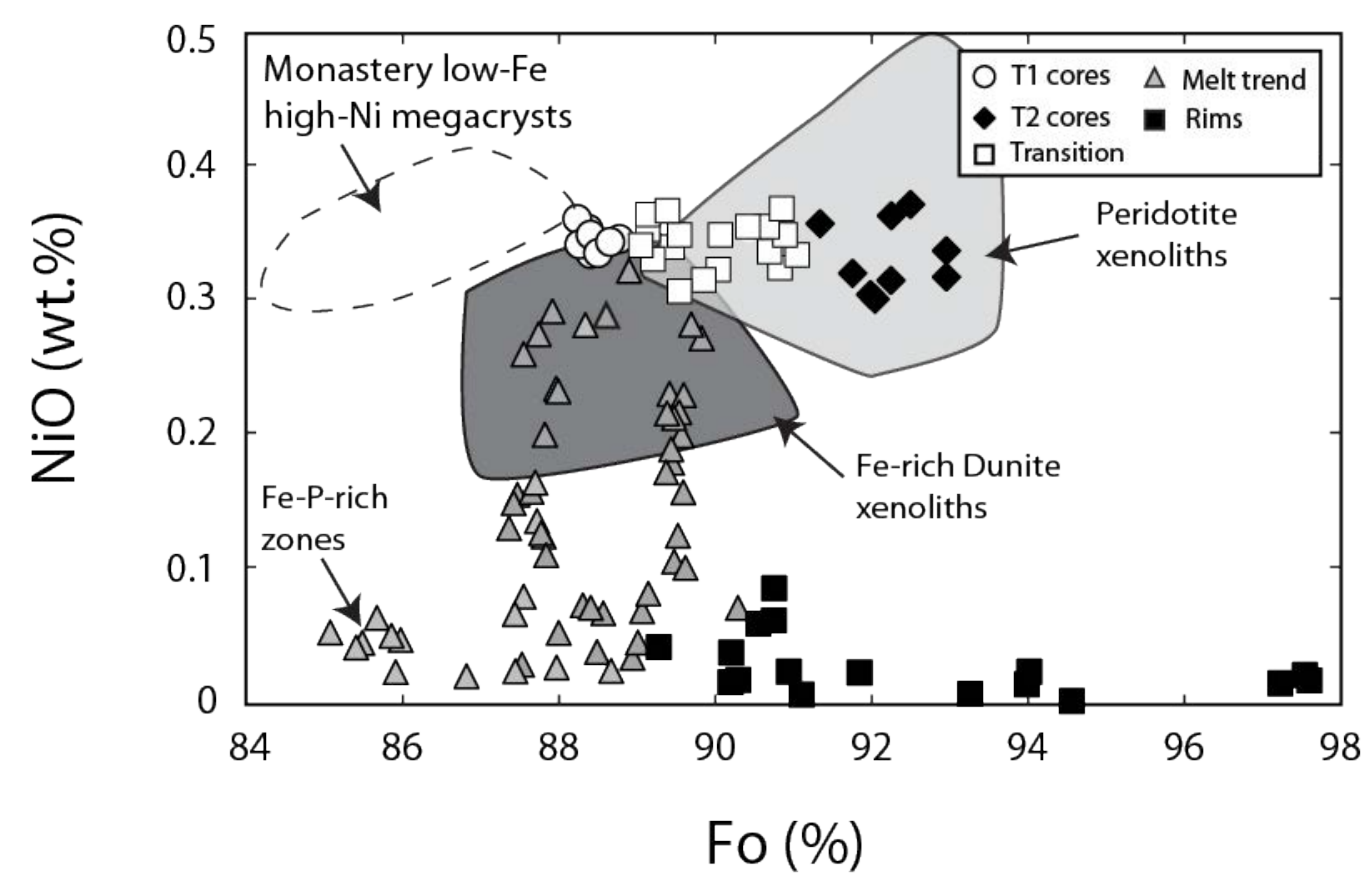


Figure 4

\section{Type 1 Olivines}
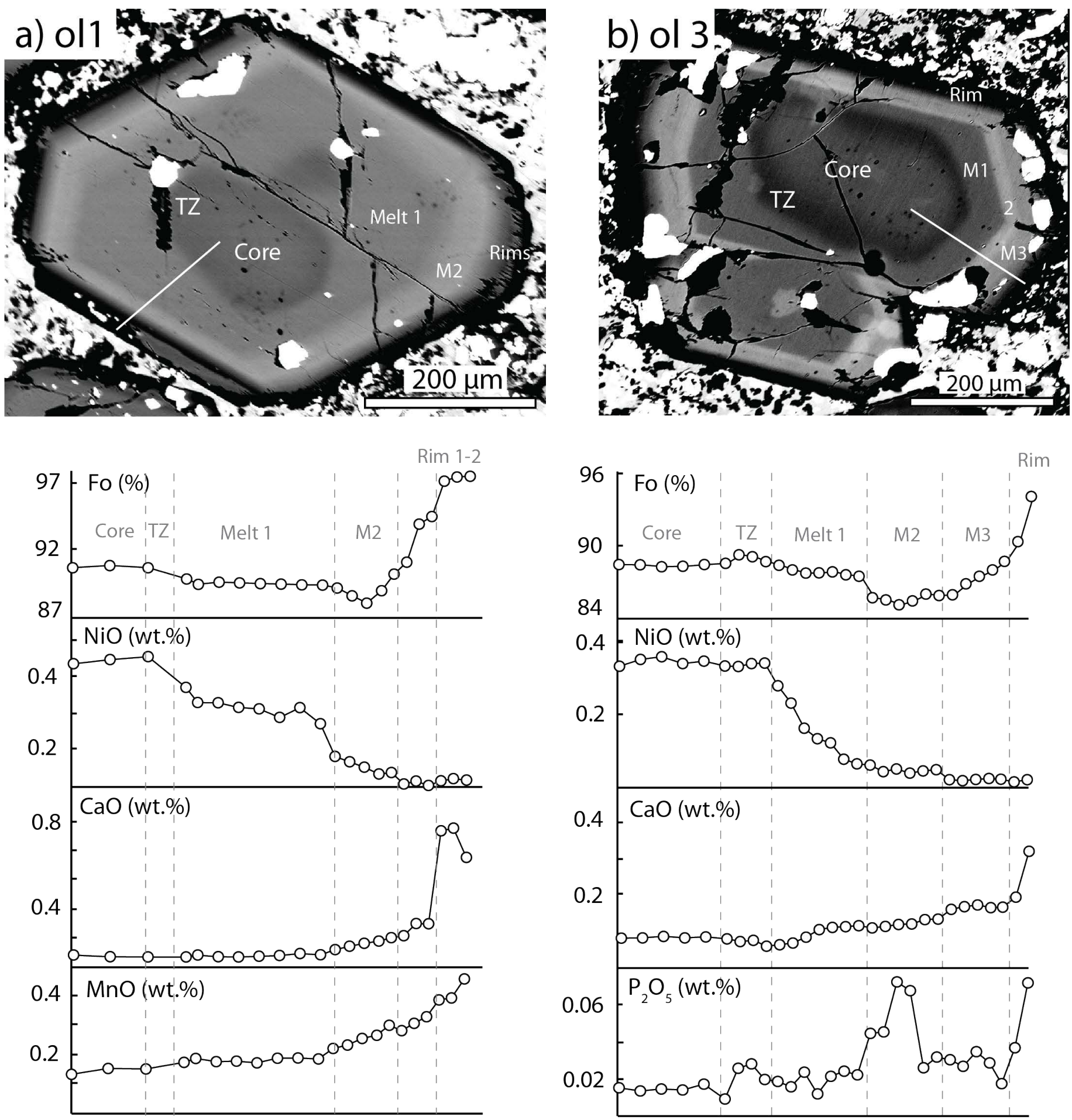


\section{Figure 5}

\section{Type 2 Olivines}
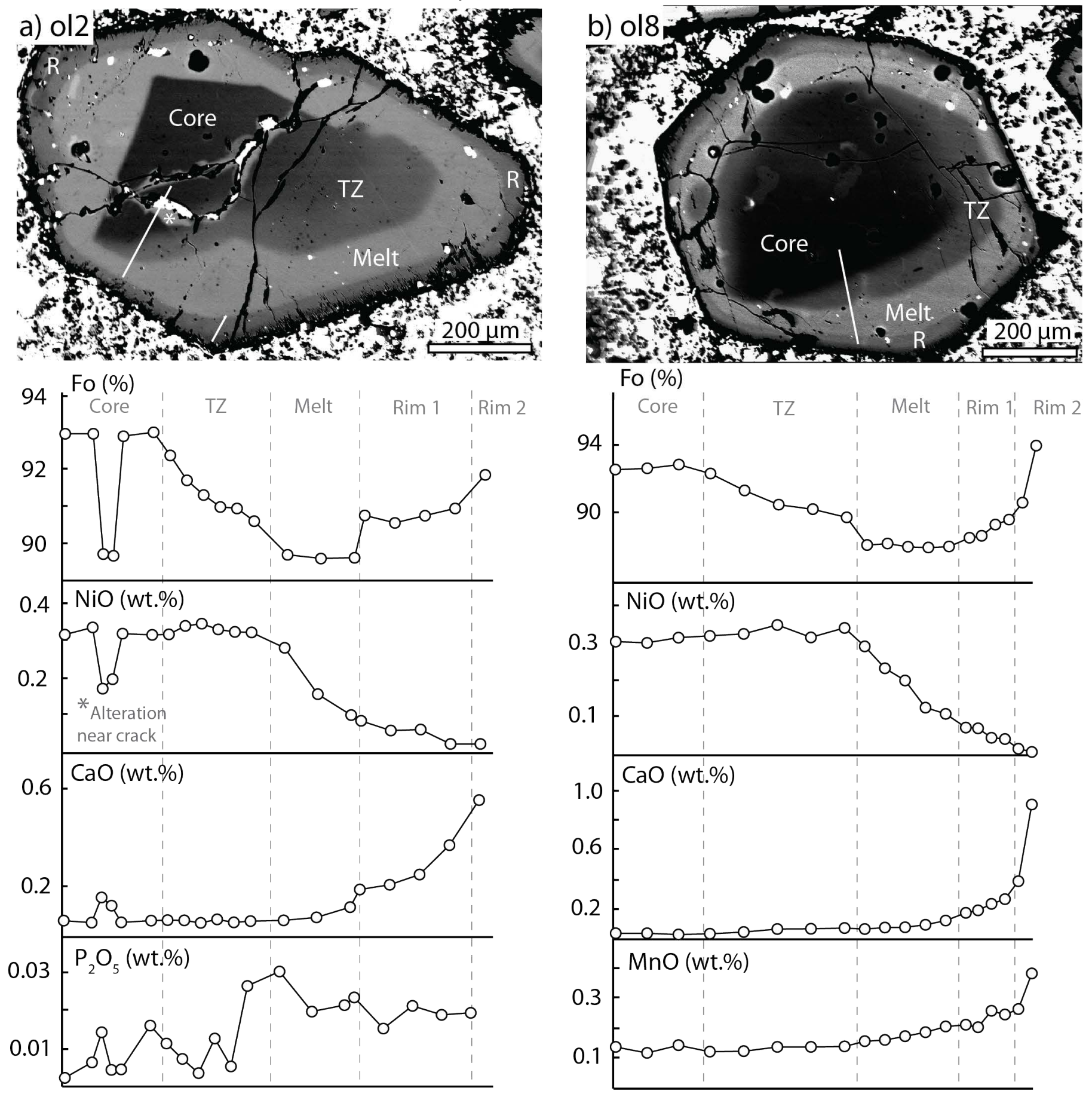


\section{Figure 6}
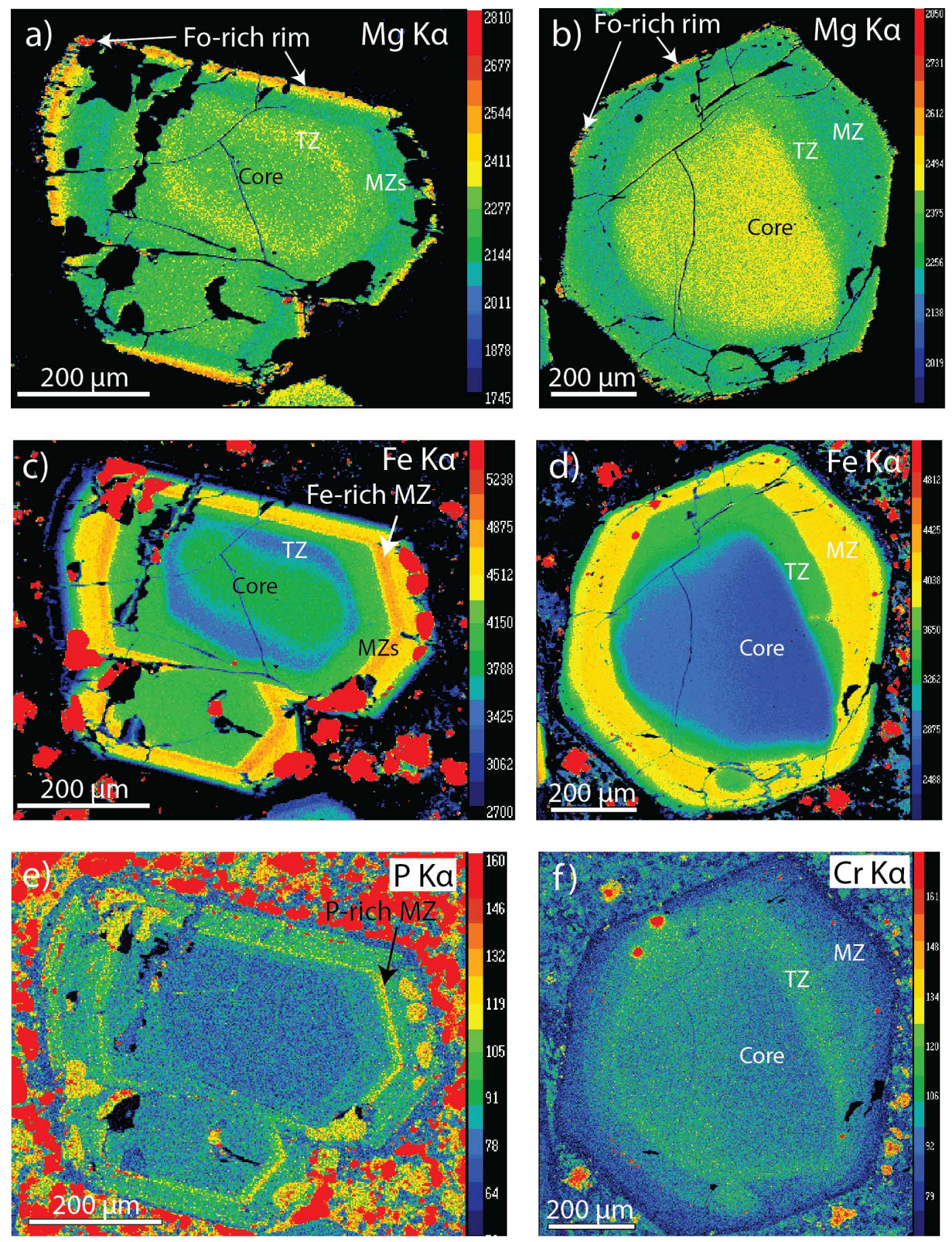
Figure 7
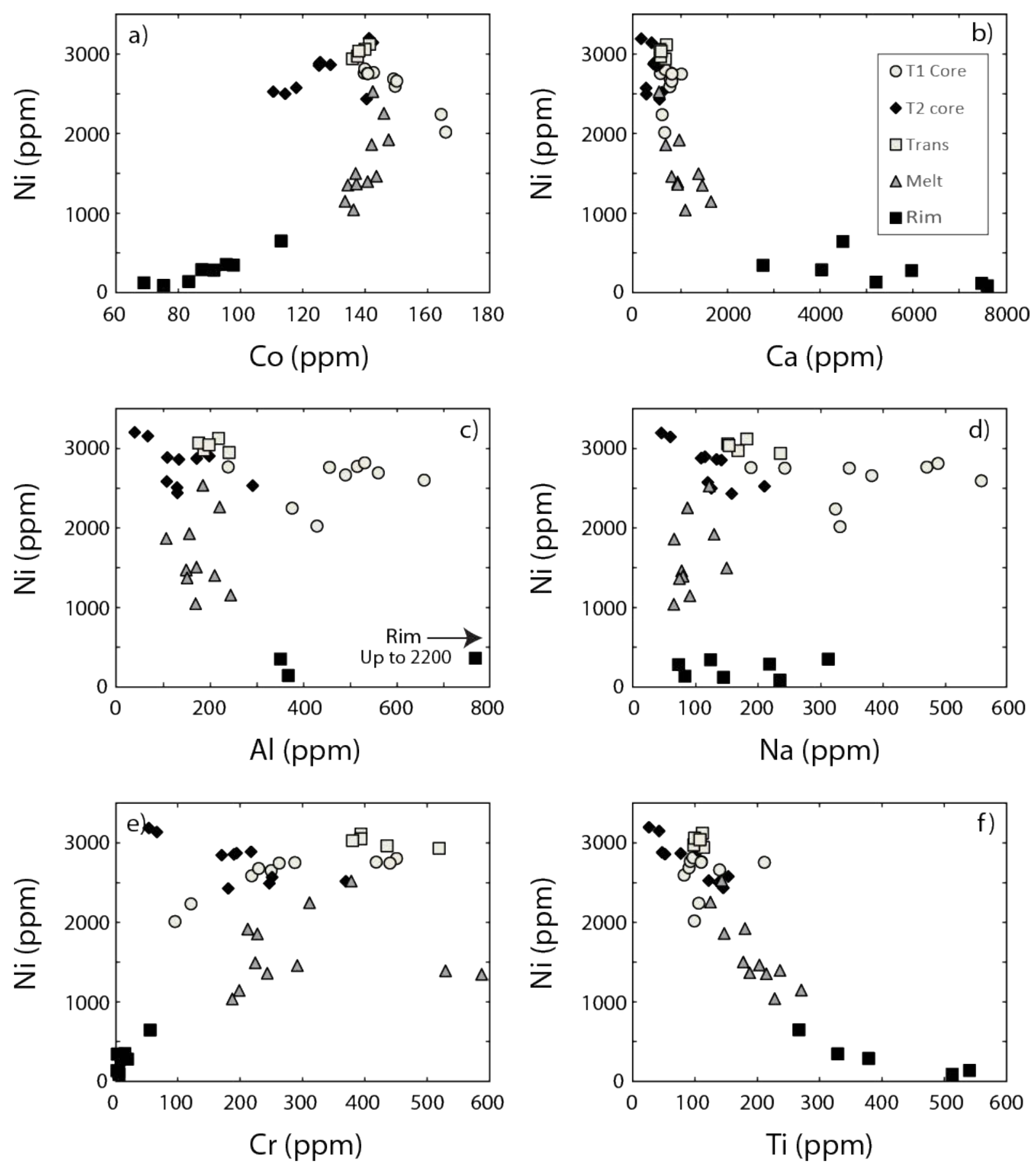


\section{Figure 8}
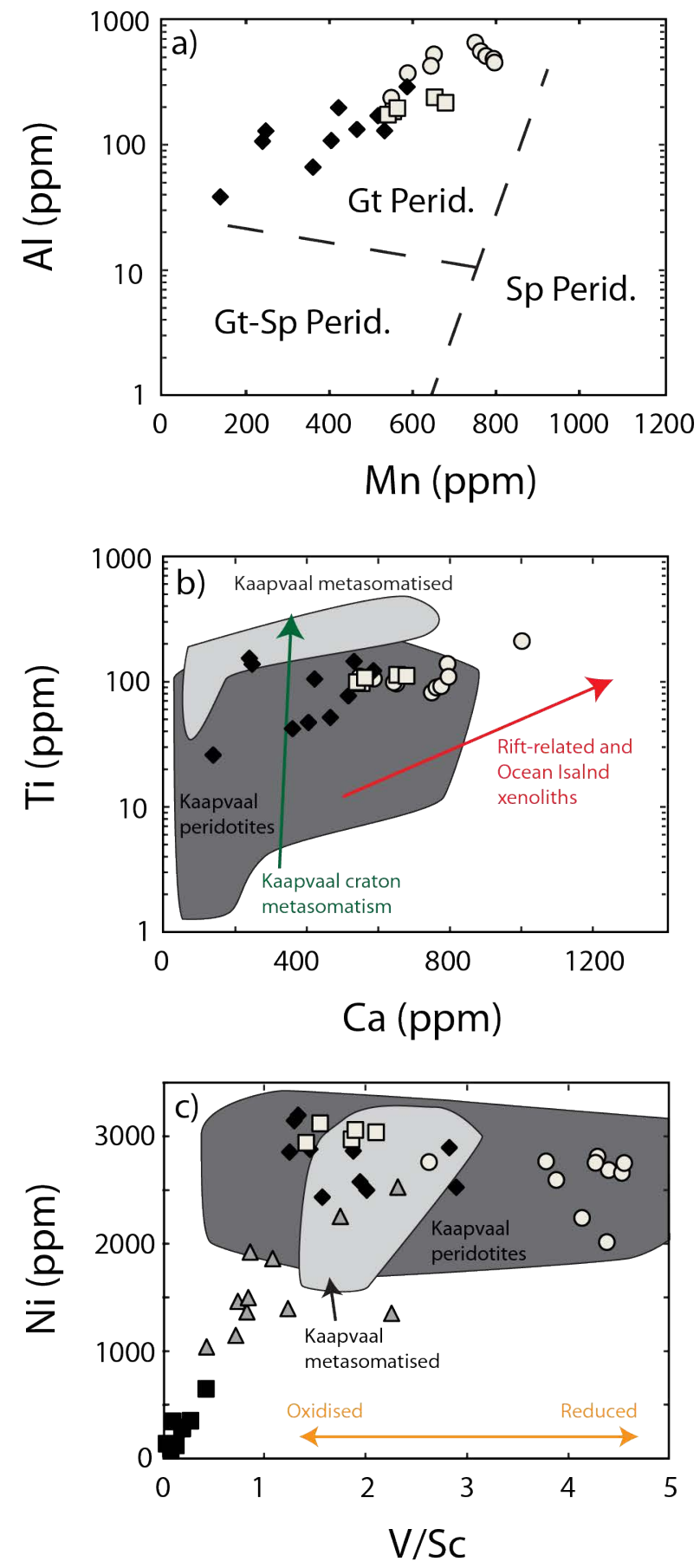


\section{Figure 9}

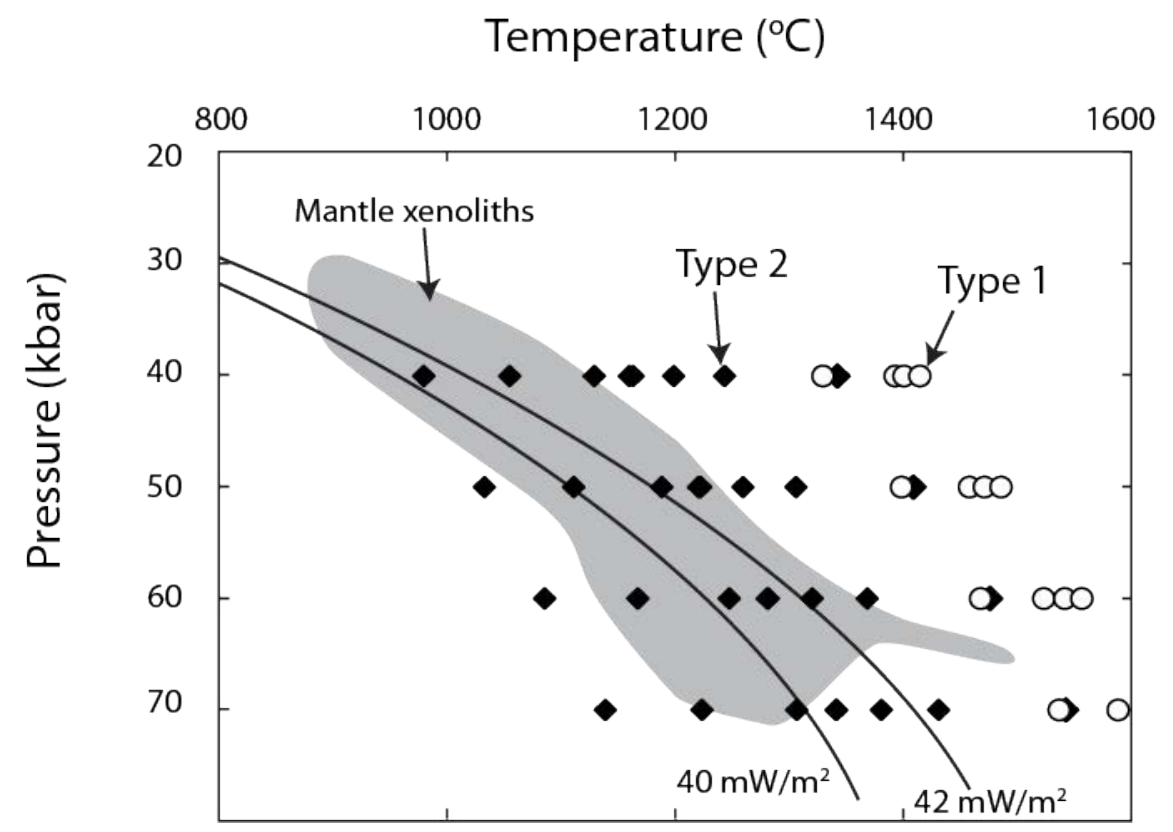




\section{Figure 10}
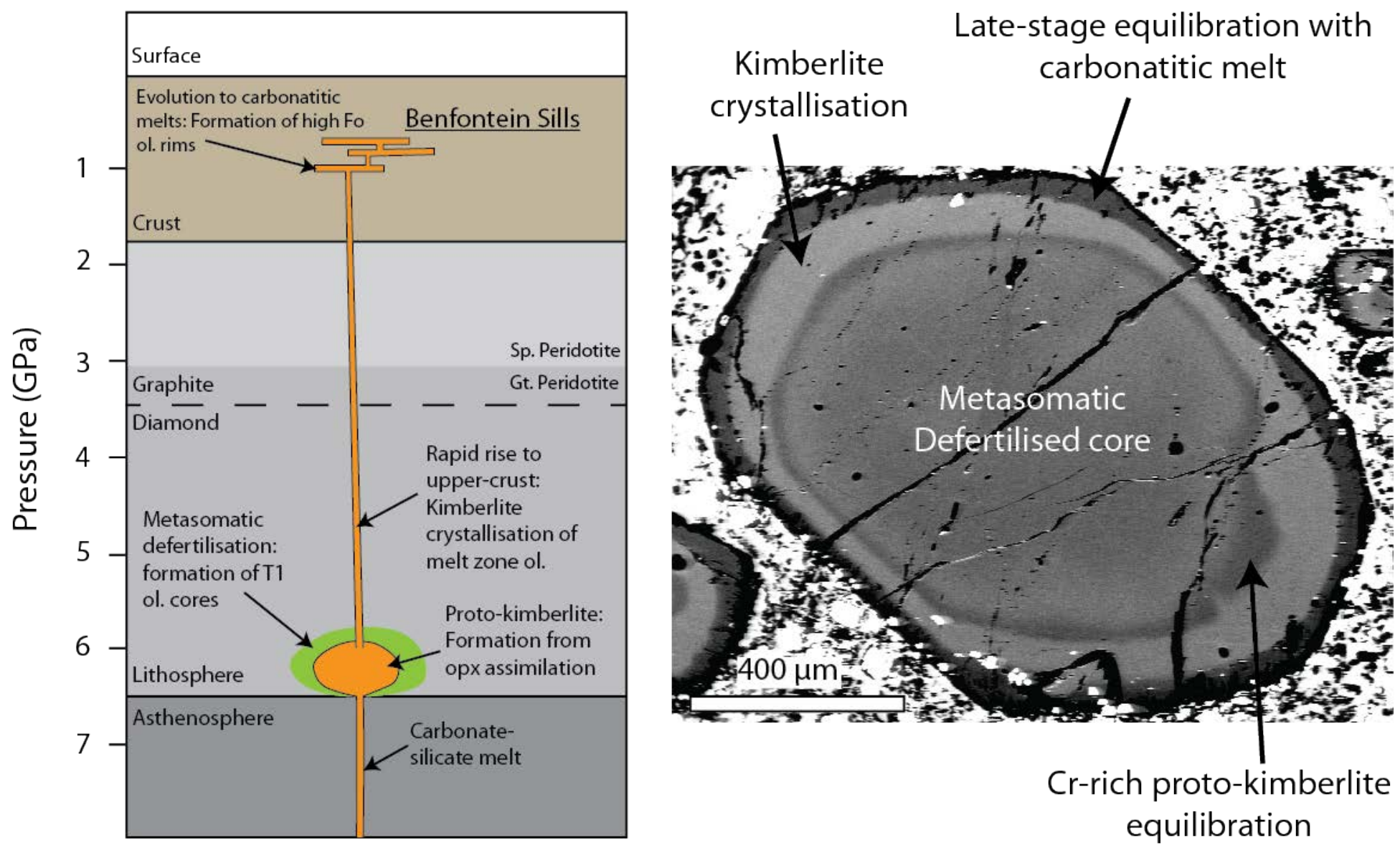